\title{
Dysregulation of TGF $\beta 1$ Activity in Cancer and Its Influence on the Quality of Anti-Tumor Immunity
}

\author{
Kristian M. Hargadon \\ Department of Biology, Hampden-Sydney College, Hampden-Sydney, VA 23943, USA; \\ khargadon@hsc.edu; Tel.: +1-1-434-223-6261 \\ Academic Editor: Andrei Turtoi \\ Received: 20 July 2016; Accepted: 29 August 2016; Published: 31 August 2016
}

\begin{abstract}
TGF $\beta 1$ is a pleiotropic cytokine that exhibits a variety of physiologic and immune regulatory functions. Although its influence on multiple cell types is critical for the regulation of numerous biologic processes in the host, dysregulation of both TGF $\beta 1$ expression and activity is frequently observed in cancer and contributes to various aspects of cancer progression. This review focuses on TGF $\beta 1$ 's contribution to tumor immune suppression and escape, with emphasis on the influence of this regulatory cytokine on the differentiation and function of dendritic cells and T cells. Clinical trials targeting TGF $\beta 1$ in cancer patients are also reviewed, and strategies for future therapeutic interventions that build on our current understanding of immune regulation by TGF $\beta 1$ are discussed.
\end{abstract}

Keywords: cancer; TGF $\beta 1$; dendritic cell; T cell; immune suppression; immunotherapy

\section{Introduction}

The transforming growth factor $\beta$ (TGF $\beta$ ) superfamily consists of more than 60 secreted proteins that play critical roles in regulating diverse biological processes during embryonic development and in adults. In particular, members of the TGF $\beta$ subfamily, of which TGF $\beta 1$ is the most well-studied isoform in mammals, have been shown to regulate various aspects of cell proliferation, differentiation, adhesion, migration, angiogenesis, apoptosis, survival and immune surveillance [1]. Because strict regulation of these processes is vital to maintaining cellular homeostasis and tissue integrity, dysregulation of TGF $\beta 1$ expression and activity has significant pathologic consequences and contributes to a number of disease states, including many cancers [2]. This review focuses on the role of TGF $\beta 1$ dysregulation in cancer-associated immune suppression and highlights how our current understanding of TGF $\beta 1$-mediated tumor immune escape is driving therapeutic interventions to target this pathway in the treatment of cancer.

\section{TGF $\beta 1$ Expression and Signaling}

TGF $\beta 1$ expression has been observed in a variety of cell types and may be driven by various stimuli that include growth factors, hormones, cytokines, interaction with apoptotic cells and TGF $\beta 1$ itself [3-8]. Transcriptional activation of the $T g f b 1$ gene is mediated by signaling through the RAS/MAPK, PI3K or PKC signaling pathways [9-11], and the androgen receptor, as well as AP-1, NFkb, Sp1 and STAT3 transcription factors have all been shown to bind to promoter elements within this gene and induce its expression [3,4,12-16]. TGF $\beta 1$ is initially translated as a latent precursor protein that must undergo extensive processing before becoming active. Details of this processing have recently been reviewed in depth elsewhere [17]. In short, proteolytic cleavage of homodimerized pro-TGF $\beta 1$ results in mature TGF $\beta 1$ peptide that is coupled to latency associated peptide (LAP). This small latent complex associates with latent TGF $\beta$ binding protein (LTBP) to form a large latent complex that is secreted into the extracellular space. Bioactive TGF $\beta 1$ protein is produced when the large latent complex and LTBP are cleaved from the mature protein in acidic environments or 
by a variety of mediators that include thrombospondin-1, integrins, reactive oxygen species and various proteases.

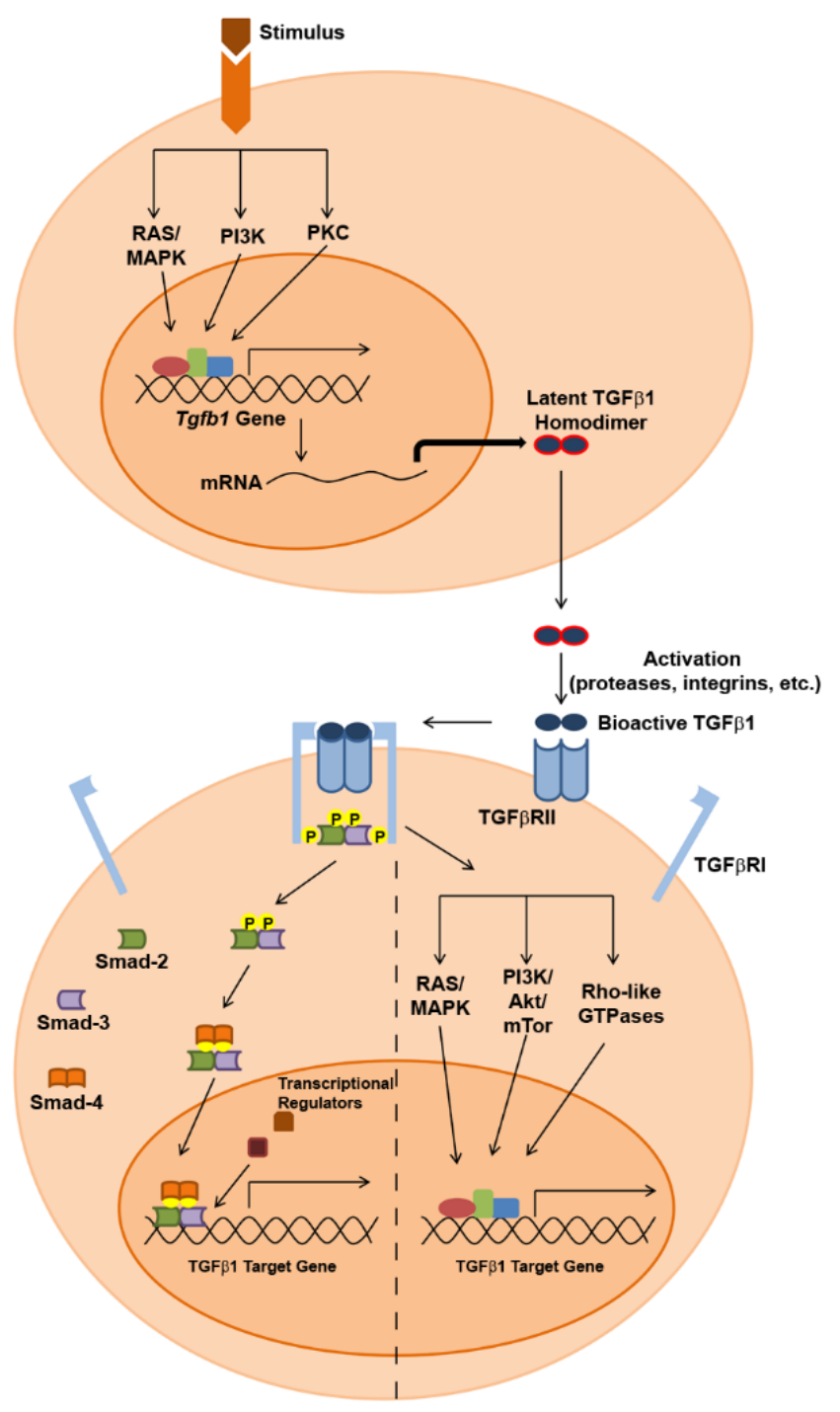

Figure 1. Summary of TGF $\beta 1$ expression and SMAD-dependent/SMAD-independent signaling pathways.

Following its activation, TGF $\beta 1$ initiates signaling in a target cell (Figure 1) by binding as a homodimer to type II TGF $\beta$ receptors (TGF $\beta$ RII), constitutively-active serine/threonine kinase receptors that undergo a conformational change upon ligand binding that enables recruitment of type I TGF $\beta$ receptors (TGF $\beta$ RI). Phosphorylation of TGF $\beta$ RI by TGF $\beta$ RII within a heterotetrameric complex then activates downstream signaling events, which can involve both SMAD-dependent and SMAD independent pathways. In SMAD-dependent signaling, phosphorylated TGF $\beta R I$ recruits and phosphorylates the receptor-activated SMADs (R-SMADs), SMAD2 and SMAD3, which in turn interact with a co-SMAD known as SMAD4. This heterotrimeric complex then translocates to the nucleus, where it interacts with various co-activator/co-repressor proteins to regulate the expression of target genes, and cell type-dependent responses to TGF $\beta 1$ signaling are influenced by the particular SMAD cofactors that associate with the R-SMAD/co-SMAD complex in specific cell types [18]. Additionally, SMAD-dependent TGF $\beta 1$ signaling can also result in epigenetic regulation of gene expression. One recent study suggests that SMAD2 is able to silence gene expression through recruitment of DNA methyltransferases to promoter regions of target genes [19], and others have 
shown that TGF $\beta 1$-SMAD signaling can promote histone acetylation and chromatin remodeling [20,21]. Finally, SMAD-independent signaling through the TGF $\beta$ RI/II receptor system can be achieved through activation of the RAS/MAPK and PI3K/Akt/mTOR pathways, as well as through activation of the Rho-like family of small GTPases. Figure 1 provides a summary of these TGF $\beta 1$ signaling pathways, which have been described more thoroughly in several recent reviews $[17,18,22,23]$.

\section{Overexpression of TGF $\beta 1$ in Cancer}

Originally recognized for its potent inhibition of cell growth [24,25], TGF $\beta 1$ has been shown to mediate anti-proliferative effects on many cell types by suppressing c-Myc expression [26,27] and altering the expression and activity of cyclin-dependent kinases (CDK) and CDK inhibitors that regulate progression through the cell cycle [28-32]. Paradoxically, despite its ability to inhibit cell proliferation, TGF $\beta 1$ is highly expressed within the tumor tissue of many cancer patients, as is evidenced by a recent interrogation of The Cancer Genome Atlas using the cBioPortal for Cancer Genomics [33,34], which revealed upregulation of TGF $\beta 1$ mRNA levels in tumors from various cancer types (Figure 2). Several other independent studies have also reported elevated TGF $\beta 1$ expression within tumor tissue or plasma of patients with various cancers. Many of these studies have correlated increased TGF $\beta 1$ expression levels with advanced tumor stage and diminished patient survival, and elevated expression of TGF $\beta 1$ in these patients is associated with several specific aspects of tumor progression that include epithelial-mesenchymal transition (EMT), angiogenesis, tissue invasion and metastasis [35-43]. Importantly, increased TGF $\beta 1$ levels in cancer may arise not only from enhanced expression of this cytokine by tumor cells themselves, but also by recruitment into the tumor microenvironment of TGF $\beta 1$-producing cancer-associated cells that include stromal fibroblasts, tumor-associated macrophages, dendritic cells, and immature myeloid cells [44-47]. The dichotomy of TGF $\beta 1$ 's anti-proliferative yet pro-tumor activities can be explained by the acquisition of tumor cell resistance to the negative regulatory effects of this cytokine during tumor progression. Indeed, decreased expression of TGF $\beta$ RI/II receptors or mutations in these proteins that abrogate TGF $\beta 1$ signaling in tumor cells have been observed in many cancer types [48-53]. Similarly, tumor cells may escape growth inhibition by autocrine/paracrine TGF $\beta 1$ signaling through alterations to SMAD signaling components. Mutations and deletions of genes encoding SMAD proteins have been observed in some cancer cells [54-57], while others have been shown to exhibit post-translational modifications to SMAD proteins that promote their cytoplasmic retention and degradation $[58,59]$. Still other tumor cells have been reported to overexpress the SMAD7 inhibitory SMAD (I-SMAD) that competitively inhibits TGF $\beta 1$-mediated SMAD signaling [60,61]. Any of these alterations to TGF $\beta 1$ signaling pathway components can shield tumor cells from the growth inhibitory effects of TGF $\beta 1$ while still allowing the tumor-promoting activities of this cytokine to be triggered in other cells within the milieu of the tumor microenvironment. Moreover, tumor cells that ultimately escape SMAD-dependent growth inhibitory signals from TGF $\beta 1$ do not necessarily become totally unresponsive to this cytokine; rather, many tumors evolve to shift TGF $\beta 1$ signals along pro-oncogenic pathways. In this light, a recent microarray analysis of gene expression in a TGF $\beta 1$-treated lung epithelial cell line versus a TGF $\beta 1$-treated lung adenocarcinoma cell line revealed differential regulation of gene expression by this cytokine in normal versus tumor cells, and the unique induction of several specific genes with tumor-promoting function by TGF $\beta 1$ in tumor cells was impaired by multiple MAPK pathway component inhibitors [62]. Similarly, other studies have shown that retention of SMAD-independent TGF $\beta 1$ signaling in late-stage tumors contributes to their progression by promoting EMT, loss of cell adhesion and increased migration/invasion [63]. Therefore, the combination of altered TGF $\beta 1$ signaling within tumor cells and traditional TGF $\beta 1$ signaling within other cell types in the tumor microenvironment results in pleiotropic effects by this cytokine that create a "perfect storm" ideally suited for tumor progression. In addition to its promotion of several of the cancer hallmarks described above (which have been reviewed extensively in many of the articles previously cited), TGF $\beta 1$ has 
also been shown to compromise the function of several cells involved in anti-tumor immune responses and, therefore, contributes significantly to tumor immune escape.

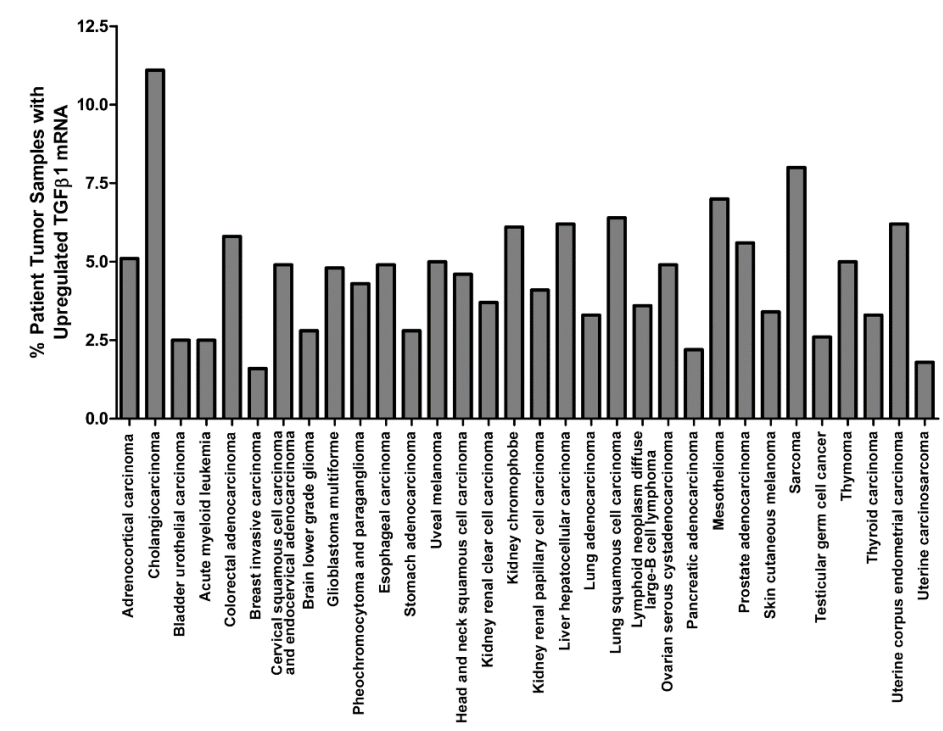

Figure 2. TGF $\beta 1$ mRNA upregulation in tumor samples as determined by RNA Seq V2 RSEM (z-score threshold = 2.0). Results were obtained from an interrogation of TCGA, provisional data on 5 June 2016 and are based on data generated by the TCGA Research Network: http:/ /cancergenome.nih.gov/.

\section{TGF $\beta 1$ in Tumor Immune Suppression and Escape}

\subsection{TGFß1 Influence on the Function of Dendritic Cells and Their Hematopoietic Precursors}

Dendritic cells (DC) are a population of innate immune cells derived from both lymphoid and myeloid progenitors that play key roles in regulating the activity of other immune cells, particularly $\mathrm{T}$ lymphocytes. Following their differentiation from hematopoietic precursors in the bone marrow, DC take up residence in both lymphoid and peripheral tissues, where they are involved in immune surveillance. As immature cells in the steady state, DC are highly phagocytic and sample antigen from various sources, though presentation of antigen by immature DC to T lymphocytes results in either immunologic ignorance or tolerance to such antigen [64-66]. On the other hand, following the encounter with various mediators that may include pathogen- or danger-associated molecular patterns, inflammatory stimuli and CD40L, immature DC become mature, activated cells that acquire potent immune stimulatory functions, which arise from their upregulation of antigen:MHC complexes, costimulatory molecules, "signal 3" cytokines and chemokines, all of which are involved in the activation and recruitment of $T$ cells and other immune effectors into an immune response $[67,68]$.

TGF $\beta 1$ is known to influence DC differentiation and function in a number of ways (Figure 3). In vitro analyses of both bone marrow- and monocyte-derived DC have shown that TGF $\beta 1$ can inhibit the development of DC from hematopoietic precursors, and those DC that do develop in the presence of TGF $\beta 1$ retain an immature phenotype characterized by low MHC class II and costimulatory molecule expression and poor T cell stimulatory activity [69-71]. Others have shown that TGF $\beta 1$ alters the differentiation program of DC precursors, leading to the development of myeloid-derived suppressor cells (MDSC) [72,73] that are known to promote tumor outgrowth through a variety of mechanisms [74,75]. In addition to its impact on the differentiation of hematopoietic precursors into DC, TGF $\beta 1$ has also been shown to interfere with the maturation and activation of fully-differentiated DC, as well. It has been shown to block the expression of the costimulatory molecules CD80 and CD86, as well as the "signal 3" cytokine IL-12 in in vitro-generated Langerhans DC [76]. Furthermore, studies using transgenic mouse models have shown the tolerogenic effects of TGF $\beta 1$ on DC in vivo, as well. For example, mice expressing a DC-restricted, CD11c promoter-driven 
dominant negative TGF $\beta$ RII receptor that lacks the kinase domain necessary for signal transduction produce DC that are resistant to TGF $\beta 1$ tolerization, resulting in aberrant, DC-dependent autoimmune T cell activation [77]. Similar findings have been reported in double transgenic mice expressing Cre recombinase under control of the CD11c promoter and a loxP-flanked Tgfbr2 gene. Inducible knockout of TGF $\beta$ RII specifically in DC of these mice leads to severe autoimmunity that is partially attributed to the inability of DC to support regulatory $\mathrm{T}$ cell (Treg) differentiation and expansion [78]. With specific regard to tumor-derived TGF $\beta 1$, recent work from our laboratory has shown that TGF $\beta 1$ in melanoma tumor-conditioned media also alters the maturation and activation of fully-differentiated tissue-resident DC. Although these tumor-altered DC could still activate CD8+ T cells in an ex vivo setting, they exhibited modified cytokine and chemokine expression profiles that correspond to a pro-tumorigenic phenotype. This phenotype could be partially reversed by $T g f b 1$ gene silencing in melanoma cells prior to ex vivo culture of tissue-derived DC in tumor-conditioned media. Of particular note among the alterations to DC function observed in our model, melanoma-derived TGF $\beta 1$ promoted DC secretion of CXCL1, a known macrophage chemoattractant, and enhanced the expression of this chemokine by lung-resident DC in mice bearing lung metastatic melanoma lesions correlated with an increase in M2-like macrophages at this site [79]. Recent findings from several other groups have also shown that TGF $\beta 1$ induces tumor-promoting functions in DC. For instance, Belladonna et al. demonstrated that TGF $\beta 1$ promotes indoleamine 2,3-dioxygenase (IDO) expression and tolerogenic activity in both CD8 - and CD8+ murine DC subsets [80], and IDO-producing regulatory DC play critical roles in anti-tumor immune suppression in various cancer types [81]. Alternatively, studies in a murine ovarian cancer model have shown that tumor-derived TGF $\beta 1$ can induce PD-L1 expression on DC that suppress T cell proliferation [82], and in patients with highly aggressive triple negative breast cancer, TGF $\beta 1$ has been shown to induce regulatory plasmacytoid DC that exhibit diminished type I IFN production and that promote expansion of CD4+ Tregs [83,84]. Collectively, these deleterious effects of TGF $\beta 1$ on DC development and function significantly compromise the quality of anti-tumor immune responses and can be a major contributing factor to tumor immune escape.

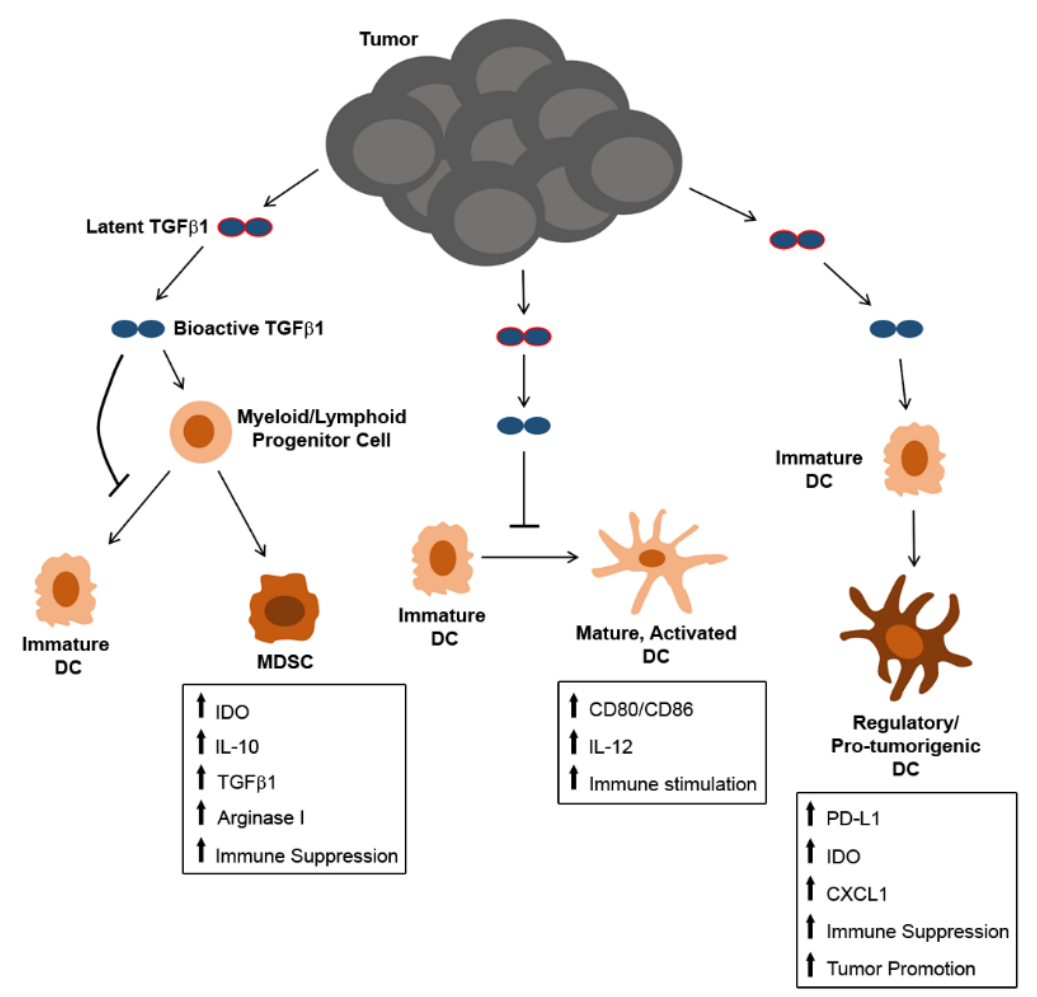

Figure 3. Overview of mechanisms by which tumor-derived TGF $\beta 1$ may influence the differentiation and function of DC and their precursors. 


\subsection{TGF $\beta 1$ Influence on Tumor-Associated Macrophages and Neutrophils}

In addition to $D C$, other immune cell populations of myeloid origin are also known to be influenced by TGF $\beta 1$. In particular, macrophages exposed to TGF $\beta 1$ have been shown to acquire an M2-like phenotype characterized by a number of tumor-promoting functions, including the ability to promote angiogenic activity, suppress $\mathrm{T}$ cell proliferation and induce CD4+ FOXP3+ Treg differentiation [85-88]. Importantly, several clinical studies have reported that patient tumors are often infiltrated by a large number of macrophages, particularly those exhibiting an anti-inflammatory, immune suppressive M2-like phenotype, and such accumulation is a negative prognostic indicator in cancer patients [89-93]. Similarly, TGF $\beta 1$ has been suggested to polarize tumor-associated neutrophils (TAN) from an N1- to an N2-like phenotype, as the blockade of TGF $\beta 1$ in several murine tumor models enhances cytotoxic activity and proinflammatory cytokine production by tumor-infiltrating neutrophils, whereas the depletion of neutrophils in the context of TGF $\beta 1$-expressing tumors diminishes tumor outgrowth and is associated with enhanced intratumoral CD8+ T cell activation [94]. As seen with M2-like macrophage accumulation within tumors, high levels of tumor-associated neutrophils in cancer patients are also associated with disease progression and poor survival $[95,96]$. Moreover, not only are these pro-tumor immune populations induced by TGF $\beta 1$, but at least in the case of tumor-associated macrophages (TAM), these cells can become potent producers of TGF $\beta 1$ themselves [97,98], thus further contributing to the immunosuppressive and tumor-promoting effects of this cytokine within the tumor microenvironment during cancer progression.

\subsection{TGFß1 Influence on T Cells}

Because of their ability to recognize highly specific antigens on the surface of a target cell, $\mathrm{T}$ lymphocytes have the potential to serve as potent immunologic effectors against tumor cells. Indeed, studies reporting increased tumor incidence in $\mathrm{RAG}^{-/-}$mice and mice deficient in the cytolytic mediator perforin highlight the role of $\mathrm{T}$ lymphocytes in immune surveillance against tumors [99-101]. Similar reports of increased tumor incidence in immunocompromised patients and transplant patients receiving immunosuppressive drug therapy [102,103], in conjunction with observations of spontaneous tumor regression in patients exhibiting natural or therapy-induced anti-tumor T cell responses [104,105], have offered support for the critical role of T cells in tumor eradication in humans, as well. However, despite the ability of $\mathrm{T}$ cells to eradicate tumors in some cases, many cases of tumor progression are associated with the induction of tumor-specific $\mathrm{T}$ cell dysfunction [106-110], thus highlighting the significance of $\mathrm{T}$ cell suppression as a contributing factor to tumor immune escape.

TGF $\beta 1$ is a well-characterized regulator of $\mathrm{T}$ cell differentiation and function. Transgenic mouse models that employ cell type-specific promoters to restrict the expression of a dominant negative TGF $\beta$ RII receptor to CD4+ or CD8+ T cells have enabled in vivo analyses of the effects of TGF $\beta 1$ on T cells and have revealed that this cytokine directly inhibits $T$ cell proliferation and activation of Th1/cytotoxic differentiation programs, while at the same time promoting the survival of Tregs [111,112]. In the context of the tumor microenvironment, therefore, various sources of TGF $\beta 1$ may contribute to $\mathrm{T}$ cell dysfunction and ultimately limit the efficacy of anti-tumor immune responses mediated by these cells. To this point, in a murine model of prostate cancer, conditional knockout of TGF $\beta$ RII in adoptively-transferred tumor-specific CD8+ T cells resulted in reduced apoptosis, increased proliferation and effector activity and delayed induction of dysfunction in these cells as compared to adoptively-transferred cells in which TGF $\beta 1$ signaling was not abrogated [113]. Although the source of TGF $\beta 1$ was not investigated in this study, others have shown that both tumors and tumor-associated cells contribute to TGF $\beta 1$-mediated anti-tumor T cell dysfunction. For instance, in the EG7 murine thymoma tumor model, membrane-bound TGF $\beta 1$ expressed on tumor apoptotic bodies has been shown to inhibit anti-tumor cytotoxic T lymphocyte (CTL) responses through the induction of CD8+ T cell anergy, while at the same time promoting the development of IL-10-producing CD4+ Tregs that inhibit CD8+ T cell proliferation and differentiation into CTL [114]. Anti-tumor 
$\mathrm{T}$ cell responses have also been shown to be inhibited by TGF $\beta 1$ derived from cells of myeloid origin $[45,115]$. With regard to CD4+ Tregs, TGF $\beta 1$ is known to promote the differentiation of these cells through induction of FOXP3 expression [116], and various tumor-associated cell types that include mesenchymal stem cells, myeloid-derived suppressor cells (MDSC), and DC have all been shown to produce TGF $\beta 1$ and induce either the proliferation or differentiation of Tregs [46,117-119]. Finally, not only does TGF $\beta 1$ contribute to the development of Tregs, but Tregs themselves suppress $\mathrm{T}$ cell function through TGF $\beta 1$ [120], and blockade of TGF $\beta 1$ signaling in CD8+ T cells has been shown to prevent Treg-mediated suppression of anti-tumor immunity in a murine colon carcinoma model [121].

In addition to inducing the differentiation of CD4+ T cells into immunosuppressive Tregs, TGF $\beta 1$ can also act in concert with IL-6 to promote CD4+ T cell differentiation along a Th17 pathway [122]. Although many studies have demonstrated anti-tumor functions of Th17 cells (reviewed in [123]), others have shown that Th17 cells exhibit pro-tumor functions in certain contexts. In both the B16 melanoma and MB49 bladder carcinoma murine tumor models, IL-17 produced by CD4+ T cells activated STAT3 in both tumor and stromal cells, leading to the expression of both anti-apoptotic and pro-angiogenic proteins within the tumor microenvironment [124]. In the EG7 murine thymoma model, IL-17 is required for the development and pro-tumor functions of MDSC [125]. IL-17 also enhances the proliferation of human colorectal cancer cell lines in vitro, and Th17 cells are enriched in tumor-infiltrating leukocyte (TIL) populations of colorectal cancer patients [126]. Likewise, in another study with multiple myeloma patients, the number of Th17 cells was increased in both the blood and bone marrow, and IL-17 was shown to stimulate the growth of human multiple myeloma cell lines in vitro and in a murine xenograft model in vivo [127]. Other clinical studies have revealed that Th17 cell infiltration and IL-17 expression levels in tumors are associated with tumor progression and poor survival in patients with gastric cancer and hepatocellular carcinoma $[128,129]$. Therefore, the influence of TGF $\beta 1$ on helper and cytotoxic T cell differentiation and function, which is summarized in Figure 4, can not only impede the anti-tumor effector functions mediated by these cells, but it can also confer tumor-promoting activity in some $\mathrm{T}$ cell populations that further drives tumor growth and metastasis.

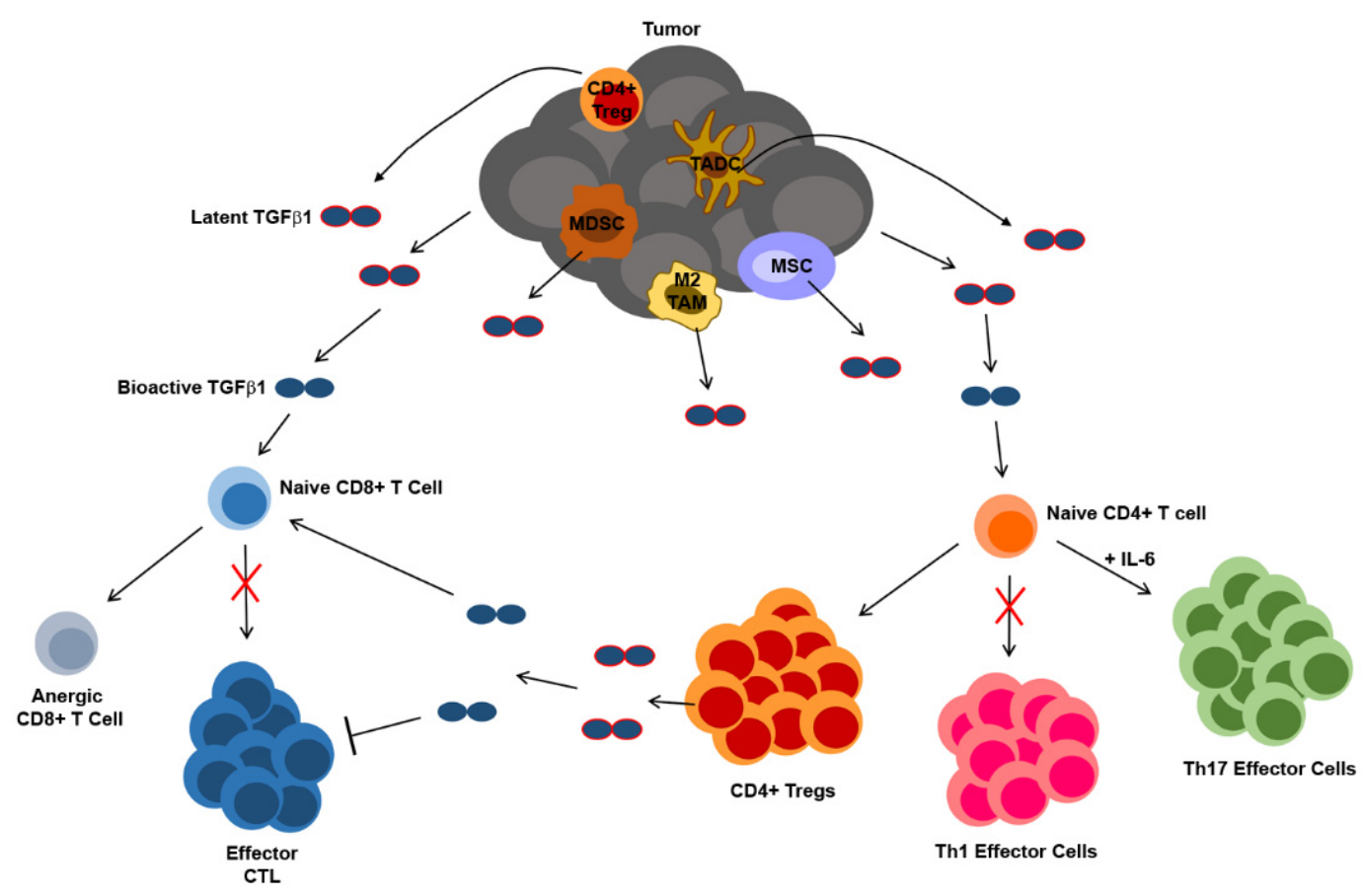

Figure 4. Summary of the mechanisms by which TGF $\beta 1$ derived from tumors and tumor-associated cells may influence the differentiation and function of CD4+ and CD8+ T lymphocytes. TADC = tumor-associated dendritic cell, TAM = tumor-associated macrophage, MSC = mesenchymal stem cell, MDSC = myeloid-derived suppressor cells, CTL = cytotoxic $\mathrm{T}$ lymphocyte, Treg $=$ regulatory $\mathrm{T}$ cell. 


\subsection{TGFß1 Influence on Natural Killer Cells}

Like effector CTL, natural killer (NK) cells may also serve as potent mediators of anti-tumor immunity. Instead of responding to specific tumor antigens as CTL do, NK cells instead respond to targets that have either downregulated MHC class I molecules or upregulated stress-associated markers, characteristics often exhibited by cancer cells during tumor progression [130]. However, in addition to its suppressive effects on the cytotoxic activity of CD8+ T cells, TGF $\beta 1$ has similarly been shown to inhibit cytotoxic effector functions in NK cells, as well. In this regard, in a murine model of liver cancer TGF $\beta 1$ expressed on the membrane of MDSC inhibited expression of the activating receptor NKG2D on hepatic NK cells, suppressed NK cell IFN $\gamma$ secretion and cytotoxicity and rendered NK cells anergic to activating stimuli [131]. TGF $\beta 1$ has also been implicated in STAT3-dependent suppression of NK cell cytotoxic activity in a murine model of hepatocellular carcinoma [132], and it is partially responsible for the downregulation of NKG2D expression and cytolytic activity by NK cells in an orthotopic model of head and neck squamous cell carcinoma [133]. One group has shown that TGF 1 1-mediated suppression of NK cell cytolytic activity is attributed to its induction of the microRNA miR-183, which silences the expression of the DAP12 adapter protein required to transmit activating signals for lytic granule mobilization [134]. Most recently, Viel et al. have shown that TGF $\beta 1$ signaling in both murine and human NK cells inhibits their activation by repressing the mTOR pathway and that deletion of TGF $\beta$ RII on NK cells restores mTOR signaling and promotes their ability to limit metastasis in multiple murine tumor models [135]. Importantly, these findings in preclinical settings have been supported by studies involving cancer patients, as well. In both lung and colorectal cancer patients, elevated plasma TGF $\beta 1$ levels correlated with decreased NKG2D expression on freshly-isolated NK cells, and downregulation of NKG2D on NK cells that were derived from healthy donors and subsequently cultured with plasma from cancer patients could be prevented by the addition of neutralizing anti-TGF $\beta 1$ monoclonal antibodies to the ex vivo cultures [136]. Likewise, TGF $\beta 1$ expression levels by tumor cells in patients with advanced gastric adenocarcinoma are inversely correlated with the cytolytic activity of NK cells isolated from the ascites and peripheral blood of these patients [137]. Taken together, these results demonstrate that TGF $\beta 1$ is a key immunosuppressive factor that confers tumor cell resistance to NK cells. In conjunction with the aforementioned discussion of TGF $\beta 1$ 's immunosuppressive effects on CTL, these findings indicate that TGF $\beta 1$ is capable of compromising both of the major cytolytic mediators associated with anti-tumor immune responses, and its influence on other cells of the immune system ultimately contributes not only to the dysfunction of these cytolytic effector cell populations, but also to the overall promotion of tumor growth and metastasis.

\section{Strategies for Interfering with TGF $\beta 1$-Mediated Suppression of Anti-Tumor Immunity}

With the emergence of data documenting the impact of TGF $\beta 1$ on the activation and function of various immune cell populations in both preclinical models and cancer patients, significant efforts have recently been made on developing therapeutic strategies for interfering with TGF $\beta 1$-mediated suppression of anti-tumor immune responses. Several approaches that either block ligand-receptor interactions or inhibit intracellular signaling cascades have been employed in a non-specific manner to systemically block TGF $\beta 1$ from influencing the behavior of target cells bearing receptors for this regulatory cytokine. Administration of a TGF $\beta$ RI kinase inhibitor augmented the immunogenicity and anti-tumor efficacy of adenoviral vector-based vaccines in multiple murine lung tumor models, promoting increased tumor infiltration of macrophages, NK cells and CD8+ T cells [138]. Similar therapeutic benefits were observed in multiple murine mesothelioma tumor models following administration of a soluble TGF $\beta$ RII chimeric protein designed to neutralize TGF $\beta 1$ (and TGF $\beta I I I)$ and thereby abrogate its signaling in target cells. Treatment of mice bearing established mesothelioma tumors with this chimeric "decoy" receptor delayed tumor outgrowth, and this control was associated with improved anti-tumor CD8+ T cell responses; specifically, mice treated with this soluble TGF $\beta$ RII protein displayed enhanced cytolytic activity in splenic CTL and increased CD8+ T cell 
infiltration of tumors, whereas no therapeutic benefit was observed in mice depleted of CD8+ T cells prior to treatment [139]. Neutralization of all three TGF $\beta$ isoforms via administration of the 1D11.16 monoclonal antibody has also been shown to significantly enhance the efficacy of a prophylactic irradiated tumor vaccine in the CT26 colorectal cancer model, and like the aforementioned mesothelioma studies, the therapeutic benefit of this treatment was dependent on CD8+ T cells, as well [140]. Still another approach involving a fusion protein known as FIST, which consists of the soluble extracellular domain of TGF $\beta$ RII linked to the immunostimulatory cytokine IL-2, has been shown to inhibit both pancreatic cancer and B16 melanoma outgrowth; while this inhibition is likely at least partially attributable to the anti-angiogenic effects of FIST, it is also associated with enhanced immune cell recruitment to tumor sites; and a soluble factor derived from NK cells was implicated in FIST-associated tumor control [141]. Additionally, as an alternative to these approaches that interfere directly with TGF $\beta 1$ or the signaling mediated by this protein, it is also possible to silence expression of the Tgfb1 gene so that the protein cannot be synthesized at normal levels. Such an approach has been implemented successfully in the B16 melanoma model, as administration of TGF $\beta 1$ siRNA in conjunction with a DC vaccine significantly enhanced the control of this tumor and was associated with a decrease in Tregs at the tumor site [142].

Despite the promise of the aforementioned approaches and similar strategies that act to systemically block TGF $\beta 1$ signaling, because of the pleiotropic regulatory activities of TGF $\beta 1$, there is concern that long-term systemic therapies targeting this pathway might have unintended and deleterious side effects [143-145]. Recently, advances in genetic engineering have enabled creative strategies to overcome this limitation and disrupt TGF $\beta 1$ signaling in specific cell populations, and several immunotherapeutic maneuvers have been developed with the aim of preventing TGF $\beta 1$-mediated suppression of either: (1) endogenous immune cell populations in the host; or (2) exogenous cells delivered as part of anti-cancer immunizations. For instance, TGF $\beta 1$ resistance has been introduced specifically into CD8 $+\mathrm{T}$ cells ex vivo by infection with a retrovirus encoding a dominant negative TGFßRII, and adoptive transfer of these T cells into tumor-bearing hosts led to significant reduction in primary tumor size and pulmonary metastases in the TRAMP-C2 transgenic adenocarcinoma of the mouse prostate model [146-148]. Improved anti-tumor CTL activity has also been observed in adoptively-transferred dominant negative TGF $\beta$ RII-expressing $T$ cells in a murine medulloblastoma tumor model [149]. Interestingly, tumor antigen-specific CD4+ and CD8+ T cells retrovirally transduced to express the dominant negative TGF $\beta$ RII each provided enhanced tumor control when transferred into B16 melanoma-bearing mice, but no therapeutic benefit resulted when adoptively-transferred $\mathrm{T}$ cells had been transduced with retrovirus encoding soluble "decoy" TGF $\beta$ RII proteins that could neutralize TGF $\beta 1$ signaling not only in T cells, but also in bystander cell populations [150]. These findings underscore the benefits of abrogating TGF $\beta 1$ signaling specifically in T lymphocytes as opposed to multiple targets in an undefined way, particularly as non-specific neutralization of TGF $\beta 1$ might interfere with its growth inhibitory effects on tumor cells that have not yet evolved to escape anti-proliferative signals conferred by TGF $\beta 1$. Moreover, the promise of inducing TGF $\beta 1$ resistance specifically in T cells is further highlighted by preclinical studies using a severe combined immunodeficient SCID xenograft model of Epstein-Barr virus (EBV)-positive lymphoma, which have revealed that EBV-specific CTL derived from patients and engineered to express dominant negative TGF $\beta$ RII also confer enhanced tumor protection as compared to TGF $\beta 1$-sensitive CTL [151]. Importantly, concerns about aberrant lymphoproliferation of TGF $\beta 1$-resistant CTL have been addressed in a non-tumor murine model using human papillomavirus E7-specific CTL, and spontaneous proliferation of dominant negative TGF $\beta$ RII-engineered CTL did not occur in the absence of antigenic stimulation [152]. 
Specific ablation of TGF $\beta 1$ signaling has also been achieved in DC that have been utilized for the purpose of cancer vaccination. Introduction of the dominant negative TGF $\beta$ RII into DC renders these cells resistant to TGF $\beta 1$-mediated suppression, and immunization of mice with tumor lysate-pulsed DC engineered in this way led to robust anti-tumor CTL responses that inhibited tumor growth and enhanced the survival of mice bearing TRAMP-C2 prostate tumors [153]. Nearly identical results were reported when dominant negative TGF $\beta$ RII-expressing DC were used to immunize mice bearing renal carcinoma metastases in the lungs [154]. As an alternative to retroviral transduction as a means of introducing TGF $\beta 1$ resistance in DC, siRNA-mediated gene silencing of the TGF $\beta$ receptor in exogenous bone marrow-derived DC also significantly improved the immunogenicity of these cells in a murine model of cervical cancer expressing the HPV-16 E7 antigen [155]. Recent work has also shown potential promise for the targeting of $T g f b 1$ (and other genes) in endogenous tumor-associated DC. Using nanocomplexes encapsulating miR-155 miRNA, Cubillos-Ruiz et al. demonstrated that preferential engulfment of these complexes by tumor-associated DC in vivo led to a reprogramming of DC function from one of immunosuppression to one of immune stimulation that in turn enhanced anti-tumor $\mathrm{T}$ cell effector function and improved the control of established ovarian carcinoma [156]. miR-155 delivery to tumor-associated DC in this model led to several changes in the transcriptome of these cells, including the silencing of $T g f b 1$ and other genes involved in the TGF $\beta 1$ signaling pathway. While these changes are likely not solely responsible for the reversal of DC function in this setting, these results highlight the potential for specific targeting of DC in situ, and future advances in our understanding of both gene regulation and cell type-specific delivery methods will undoubtedly allow scientists to fine-tune approaches for interfering with TGF $\beta 1$ production by, or signaling within, particular cell populations. Moreover, though it has yet to be explored with respect to TGF $\beta 1$ 's influence on anti-tumor immune responses, advances in genome editing strategies, such as CRISPR-Cas9 approaches that can be tailored to target gene function at the level of DNA, offer exciting promise for the permanent disruption of genes in specific cells and, therefore, might have an advantage over gene silencing approaches that confer only a temporary diminution in target gene expression. Particularly in the context of exogenous DC or CTL used for cancer vaccination and adoptive transfer therapies, it is appealing to speculate that permanent disruption of the Tgfbr2 gene by genome editing might further improve the immunogenicity of these cells as compared to cells altered by less permanent gene silencing approaches. Such genome editing would also likely carry advantages over viral vector-based methods of introducing into these immune cell populations a dominant negative TGF $\beta$ receptor, which can confer permanent resistance to TGF $\beta 1$ signaling, but which may allow for random integration of viral vectors into the genome and functional disruption of unintended genes or the expression of viral antigens in transduced cells that ultimately flag them for destruction by the immune system, thus preventing any long-term immunologic benefit.

\section{Clinical Trials Targeting TGF $\beta 1$ in the Context of Cancer Immunotherapy}

The accumulation of data over the last 30 years that TGF $\beta 1$ plays several key roles in the progression of cancer and increasing evidence from animal and preclinical studies demonstrating the anti-tumor efficacy of many strategies that interfere with TGF $\beta 1$ activity have together made TGF $\beta 1$ an attractive target for cancer therapy in patients. Indeed, several TGF $\beta 1$ pathway inhibitors have been or are currently being tested in clinical trials for various cancer types. These inhibitors include monoclonal antibodies to TGF $\beta 1$ or TGF $\beta$ receptors that aim to prevent ligand-receptor interactions, TGF $\beta 1$ peptide inhibitors and small molecule inhibitors that aim to block TGF $\beta 1$ signal transduction at the intracellular level. Clinical trials utilizing these inhibitors have recently been reviewed elsewhere [157]. Only one of these inhibitors (GC1008, a monoclonal pan-TGF $\beta$ neutralizing antibody otherwise known as fresolimumab) has been evaluated for its impact on immune cell populations in cancer patients, and it was shown to have no impact on Treg frequency or the expression of activation markers on CD4+ $\mathrm{T}$ cells, CD8+ T cells or NK cells in patients with malignant pleural mesothelioma (MPM). Although this study did demonstrate increased levels of serum antibodies that could react with MPM tumor 
lysates (but that could not bind live MPM cell lines) following treatment, the number of patients ultimately enrolled in the study was limited due to discontinuation of antibody development for oncology indications [158]. While some TGF $\beta 1$ inhibitors have shown promise in early-phase trials, others have also been abandoned [157]. As alluded to in the previous section, though, strategies that aim to specifically target TGF $\beta 1$ signaling in immune cell populations might be more advantageous than TGF $\beta$ pathway inhibitors that block signaling systemically, and several ongoing clinical trials are currently incorporating such strategies into novel cancer immunotherapies (Table 1).

Table 1. Ongoing cancer clinical trials targeting TGF $\beta 1$ to improve immunotherapy. Clinical trial information obtained from ClinicalTrials.gov.

\begin{tabular}{|c|c|c|c|}
\hline Trial Identifier & Description of Therapy & Cancer & Status \\
\hline \multicolumn{4}{|c|}{ Adoptive Cell Transfer Therapies } \\
\hline NCT00368082 & LMP-specific DNR-CTL & EBV+ lymphoma & $\begin{array}{l}\text { Phase I; ongoing, } \\
\text { not recruiting }\end{array}$ \\
\hline NCT02065362 & $\begin{array}{l}\text { LMP/BARF1/EBNA1-specific } \\
\text { DNR-CTL } \pm \text { lymphodepletion }\end{array}$ & EBV+ nasopharyngeal carcinoma & $\begin{array}{c}\text { Phase I; } \\
\text { currently recruiting }\end{array}$ \\
\hline NCT00889954 & HER2 CAR/EBV-specific DNR-CTL & $\begin{array}{l}\text { Advanced stage } \\
\text { HER2+ malignancies }\end{array}$ & $\begin{array}{l}\text { Phase I; ongoing, } \\
\text { not recruiting }\end{array}$ \\
\hline NCT02379520 & E6/E7-specific DNR-CTL & HPV-related/HPV+ cancers & Phase I; recruiting \\
\hline NCT01955460 & $\begin{array}{c}\text { Lymphodepletion + DNRII TIL + } \\
\text { high-dose IL-2 }\end{array}$ & Melanoma & Phase I; recruiting \\
\hline \multicolumn{4}{|c|}{ Autologous Tumor Cell Vaccines } \\
\hline NCT01061840 & $\begin{array}{l}\text { Vigil }^{\mathrm{TM}}\left(\mathrm{FANG}^{\mathrm{TM}}\right) \text { bi-shRNAfurin }+ \\
\text { GM-CSF vaccine }\end{array}$ & $\begin{array}{l}\text { Ewing sarcoma, non-small cell lung } \\
\text { cancer, liver cancer, thyroid cancer }\end{array}$ & $\begin{array}{l}\text { Phase I; ongoing, } \\
\text { not recruiting }\end{array}$ \\
\hline NCT01453361 & $\begin{array}{l}\text { Vigil }^{\mathrm{TM}}\left(\mathrm{FANG}^{\mathrm{TM}}\right) \text { bi-shRNAfurin }+ \\
\text { GM-CSF vaccine }\end{array}$ & Advanced melanoma (Stage IIIc/IV) & $\begin{array}{l}\text { Phase II; ongoing, } \\
\text { not recruiting }\end{array}$ \\
\hline NCT01505166 & $\begin{array}{l}\text { Vigil }^{\mathrm{TM}}\left(\text { FANG }^{\mathrm{TM}}\right) \text { bi-shRNAfurin }+ \\
\text { GM-CSF vaccine }\end{array}$ & $\begin{array}{l}\text { Colorectal carcinoma with } \\
\text { liver metastases }\end{array}$ & $\begin{array}{l}\text { Phase II; ongoing, } \\
\text { not recruiting }\end{array}$ \\
\hline
\end{tabular}

Adoptive transfer of tumor antigen-specific CTL has become one of the most promising immunotherapies for the treatment of cancer. Because TGF $\beta 1$ is known to compromise CTL effector function, several trials have been designed to investigate whether introducing TGF $\beta 1$ resistance into adoptively-transferred CTL can boost the anti-tumor efficacy of these cells. Following up on the promise of the preclinical studies described above, trials involving dominant negative TGF $\beta$ receptor-expressing CTL (DNR-CTL) are currently underway for several cancers. TGF $\beta$-resistant CTL specific for LMP antigens of EBV are being used for adoptive transfer therapy of patients with EBV+ lymphoma. A similar trial comparing the adoptive transfer of EBV-specific DNR-CTL with or without chemotherapy-induced lymphodepletion is also ongoing for patients with EBV+ nasopharyngeal carcinoma. In an approach to target multiple tumor antigens with the same adoptively-transferred CTL, a chimeric antigen receptor (CAR) specific for the human epidermal growth factor receptor 2 (HER2) has been introduced into EBV-specific DNR-CTL generated from the blood of EBV seropositive patients for investigation in patients with HER2+ malignancies. Human papilloma virus-associated cancers are also being targeted with HPV E7 antigen-specific DNR-CTL. Finally, in contrast to the previously described approaches in which CTL are generated from patient blood, tumor-infiltrating lymphocytes from patients with metastatic melanoma are also being engineered to express the dominant negative TGFßRII prior to adoptive transfer therapy in conjunction with high-dose IL-2.

Clinical trials incorporating strategies to limit TGF $\beta 1$-mediated immune suppression have not been restricted solely to adoptive $\mathrm{T}$ cell transfer therapies either. The Vigil ${ }^{\mathrm{TM}}$ (formerly known as FANG ${ }^{\mathrm{TM}}$ ) vaccine, which consists of autologous tumor cells transfected with a plasmid vector encoding both granulocyte-macrophage colony-stimulating factor (GM-CSF) and a bi-functional 
shRNA designed to silence expression of the furin convertase that activates both TGF $\beta 1$ and TGF $\beta 2$, has already been validated in a phase I trial involving patients with various late-stage cancers [159]. In this trial, the Vigil ${ }^{\mathrm{TM}}\left(\mathrm{FANG}^{\mathrm{TM}}\right)$ vaccine was well tolerated with minimal adverse events, and the expression of TGF $\beta 1$ and TGF $\beta 2$ was decreased $93.5 \%$ and $92.5 \%$, respectively. Survival was significantly enhanced in patients receiving $\geq 4$ vaccines, and $50 \%$ of this group's patients whose PBMC were tested for reactivity against autologous tumor cells showed an increase in IFN $\gamma$-producing cells by Enzyme-Linked ImmunoSpot ELISPOT analysis. Similar immunologic and clinical benefits from this vaccine have since been reported in follow-up studies $[160,161]$ and in a phase I trial involving patients with advanced Ewing sarcoma $[162,163]$. Although the exact mechanism of improved immune reactivity achieved by Vigil ${ }^{\mathrm{TM}}\left(\mathrm{FANG}^{\mathrm{TM}}\right)$ vaccination is less clear than DNR-CTL adoptive transfer therapies in which TGF $\beta$ resistance is introduced specifically into T cells, it is likely that indirect TGF $\beta$ knockdown via this approach diminishes the suppression of DC, whose recruitment to and activation at the vaccination site is also enhanced by GM-CSF secreted by the engineered autologous tumor cells. By employing autologous tumor cells that have the potential to promote immune reactivity against several patient-specific tumor antigens, the "triad" functionality of Vigil ${ }^{\mathrm{TM}}$ (FANG ${ }^{\mathrm{TM}}$ ) vaccination is achieved, creating possible advantages over adoptive cell transfer therapies that target only a single tumor antigen and that are restricted to only a subset of patients whose tumors test positive for such a targeted antigen. Based on the promise of the documented phase I trials thus far, other phase I/II Vigil $^{\mathrm{TM}}\left(\mathrm{FANG}^{\mathrm{TM}}\right)$ trials are currently in progress for patients with melanoma, colorectal carcinoma and various other advanced solid tumors.

\section{Conclusions and Future Perspectives}

Since the discovery of TGF $\beta 1$ more than 30 years ago, significant research efforts have been focused on understanding the biology of this potent regulatory cytokine. During this time, much has been learned about TGF $\beta 1$ 's role in regulating a diverse array of physiologic processes, both in the steady state and in the development of disease. Its dysregulation in cancer specifically has emerged as a major driver of tumor progression, and TGF $\beta 1$ is now known to influence several hallmarks of cancer that include angiogenesis, tissue invasion, metastasis and immune suppression. In particular, our understanding of TGF $\beta 1$-mediated immune suppression in cancer has provided significant insights into tumor immune escape and has paved the way for therapeutic strategies that aim to improve the efficacy of immune-based cancer treatment modalities. Many of these strategies have shown promise in preclinical models and even in early clinical trials, particularly as technologies have emerged to modify TGF $\beta 1$ activity in specific cell populations. As we continue to learn more about the pleiotropic activities of TGF $\beta 1$ and the context-dependent nature of these activities within the tumor microenvironment, and as new advances in genetic engineering and genome editing continue to emerge, novel approaches for both therapeutic delivery and TGF $\beta 1$ targeting are likely to improve the quality of anti-tumor immune responses in cancer patients. Data obtained from ongoing/future clinical trials and new preclinical studies will also be important for (1) gaining insights into factors that regulate the efficacy of TGF $\beta 1$-targeted therapies and (2) identifying patient populations most likely to benefit from such therapies. Moreover, an improved understanding of factors that limit the efficacy of TGF $\beta 1$-targeted regimens in some patients might also suggest combinatorial approaches for therapy that may improve treatment outcome for cancer patients in the future.

Acknowledgments: Research at the Hargadon Laboratory is supported by grant funding from Virginia's Commonwealth Health Research Board and the Jeffress Trust Awards Program in Interdisciplinary Research (The Thomas F. and Kate Miller Jeffress Memorial Trust, Bank of America, N.A., Trustee) and by generous donations from Michael Hargadon and Patricia Hargadon to support the involvement of undergraduates in research at Hampden-Sydney College. Funds to cover open access publishing of this article were generously provided by Hampden-Sydney College.

Conflicts of Interest: The author declares no conflict of interest. The founding sponsors had no role in the writing of the manuscript, nor in the decision to publish the results. 


\section{References}

1. Massagué, J. How cells read TGF-beta signals. Nat. Rev. Mol. Cell Biol. 2000, 1, 169-178. [CrossRef] [PubMed]

2. Gordon, K.J.; Blobe, G.C. Role of transforming growth factor-beta superfamily signaling pathways in human disease. Biochim. Biophys. Acta 2008, 1782, 197-228. [CrossRef] [PubMed]

3. Qi, W.; Gao, S.; Wang, Z. Transcriptional regulation of the TGF-beta1 promoter by androgen receptor. Biochem. J. 2008, 416, 453-462. [CrossRef] [PubMed]

4. Sullivan, D.E.; Ferris, M.; Nguyen, H.; Abboud, E.; Brody, A.R. TNF-alpha induces TGF-beta1 expression in lung fibroblasts at the transcriptional level via AP-1 activation. J. Cell. Mol. Med. 2009, 13, 1866-1876. [CrossRef] [PubMed]

5. Fraser, D.; Brunskill, N.; Ito, T.; Phillips, A. Long-term exposure of proximal tubular epithelial cells to glucose induces transforming growth factor-beta 1 synthesis via an autocrine PDGF loop. Am. J. Pathol. 2003, 163, 2565-2574. [CrossRef] [PubMed]

6. Bascom, C.C.; Wolfshohl, J.R.; Coffey, R.J.; Madisen, L.; Webb, N.R.; Purchio, A.R.; Derynck, R.; Moses, H.L. Complex regulation of transforming growth factor beta 1 , beta 2 , and beta 3 mRNA expression in mouse fibroblasts and keratinocytes by transforming growth factors beta 1 and beta 2. Mol. Cell. Biol. 1989, 9, 5508-5515. [CrossRef] [PubMed]

7. Xiao, Y.Q.; Freire-de-Lima, C.G.; Schiemann, W.P.; Bratton, D.L.; Vandivier, R.W.; Henson, P.M. Transcriptional and translational regulation of TGF-beta production in response to apoptotic cells. J. Immunol. 2008, 181, 3575-3585. [CrossRef] [PubMed]

8. Chegini, N.; Tang, X.M.; Ma, C. Regulation of transforming growth factor-beta1 expression by granulocyte macrophage-colony-stimulating factor in leiomyoma and myometrial smooth muscle cells. J. Clin. Endocrinol. Metab. 1999, 84, 4138-4143. [PubMed]

9. Grewal, J.S.; Mukhin, Y.V.; Garnovskaya, M.N.; Raymond, J.R.; Greene, E.L. Serotonin 5-HT2A receptor induces TGF-beta1 expression in mesangial cells via ERK: Proliferative and fibrotic signals. Am. J. Physiol. 1999, 276, F922-F930. [PubMed]

10. Li, Z.-D.; Bork, J.P.; Krueger, B.; Patsenker, E.; Schulze-Krebs, A.; Hahn, E.G.; Schuppan, D. VEGF induces proliferation, migration, and TGF-beta1 expression in mouse glomerular endothelial cells via mitogen-activated protein kinase and phosphatidylinositol 3-kinase. Biochem. Biophys. Res. Commun. 2005, 334, 1049-1060. [CrossRef] [PubMed]

11. Yue, J.; Mulder, K.M. Requirement of Ras/MAPK pathway activation by transforming growth factor beta for transforming growth factor beta 1 production in a Smad-dependent pathway. J. Biol. Chem. 2000, 275, 30765-30773. [CrossRef] [PubMed]

12. Birchenall-Roberts, M.C.; Ruscetti, F.W.; Kasper, J.; Lee, H.D.; Friedman, R.; Geiser, A.; Sporn, M.B.; Roberts, A.B.; Kim, S.J. Transcriptional regulation of the transforming growth factor beta 1 promoter by v-src gene products is mediated through the AP-1 complex. Mol. Cell. Biol. 1990, 10, 4978-4983. [CrossRef] [PubMed]

13. Lee, K.-Y.; Ito, K.; Hayashi, R.; Jazrawi, E.P.I.; Barnes, P.J.; Adcock, I.M. NF-kappaB and activator protein 1 response elements and the role of histone modifications in IL-1beta-induced TGF-beta1 gene transcription. J. Immunol. 2006, 176, 603-615. [CrossRef] [PubMed]

14. Geiser, A.G.; Busam, K.J.; Kim, S.J.; Lafyatis, R.; O’Reilly, M.A.; Webbink, R.; Roberts, A.B.; Sporn, M.B. Regulation of the transforming growth factor-beta 1 and -beta 3 promoters by transcription factor Sp1. Gene 1993, 129, 223-228. [CrossRef] [PubMed]

15. Kim, S.; Glick, A.; Sporn, M.; Roberts, A. Characterization of the promoter region of the human transforming growth factor-beta 1 gene. J. Biol. Chem. 1989, 264, 402-408. [PubMed]

16. Kinjyo, I.; Inoue, H.; Hamano, S.; Fukuyama, S.; Yoshimura, T.; Koga, K.; Takaki, H.; Himeno, K.; Takaesu, G.; Kobayashi, T.; et al. Loss of SOCS3 in T helper cells resulted in reduced immune responses and hyperproduction of interleukin 10 and transforming growth factor-beta 1. J. Exp. Med. 2006, 203, 1021-1031. [CrossRef] [PubMed]

17. Kubiczkova, L.; Sedlarikova, L.; Hajek, R.; Sevcikova, S. TGF- $\beta$-An excellent servant but a bad master. J. Transl. Med. 2012, 10, 183. [CrossRef] [PubMed]

18. Massagué, J.; Seoane, J.; Wotton, D. Smad transcription factors. Genes Dev. 2005, 19, 2783-2810. [CrossRef] [PubMed] 
19. Papageorgis, P.; Lambert, A.W.; Ozturk, S.; Gao, F.; Pan, H.; Manne, U.; Alekseyev, Y.O.; Thiagalingam, A.; Abdolmaleky, H.M.; Lenburg, M.; et al. Smad signaling is required to maintain epigenetic silencing during breast cancer progression. Cancer Res. 2010, 70, 968-978. [CrossRef] [PubMed]

20. Ross, S.; Cheung, E.; Petrakis, T.G.; Howell, M.; Kraus, W.L.; Hill, C.S. Smads orchestrate specific histone modifications and chromatin remodeling to activate transcription. EMBO J. 2006, 25, 4490-4502. [CrossRef] [PubMed]

21. Xi, Q.; Wang, Z.; Zaromytidou, A.-I.; Zhang, X.H.-F.; Chow-Tsang, L.-F.; Liu, J.X.; Kim, H.; Barlas, A.; Manova-Todorova, K.; Kaartinen, V.; et al. A poised chromatin platform for TGF- $\beta$ access to master regulators. Cell 2011, 147, 1511-1524. [CrossRef] [PubMed]

22. Chaudhury, A.; Howe, P.H. The tale of transforming growth factor-beta (TGFbeta) signaling: A soigné enigma. IUBMB Life 2009, 61, 929-939. [CrossRef] [PubMed]

23. Papageorgis, P. TGF $\beta$ signaling in tumor initiation, epithelial-to-mesenchymal transition, and metastasis. J. Oncol. 2015, 2015, 587193. [CrossRef] [PubMed]

24. Tucker, R.F.; Shipley, G.D.; Moses, H.L.; Holley, R.W. Growth inhibitor from BSC-1 cells closely related to platelet type beta transforming growth factor. Science 1984, 226, 705-707. [CrossRef] [PubMed]

25. Ristow, H.J. BSC-1 growth inhibitor/type beta transforming growth factor is a strong inhibitor of thymocyte proliferation. Proc. Natl. Acad. Sci. USA 1986, 83, 5531-5533. [CrossRef] [PubMed]

26. Fernandez-Pol, J.A.; Talkad, V.D.; Klos, D.J.; Hamilton, P.D. Suppression of the EGF-dependent induction of c-myc proto-oncogene expression by transforming growth factor beta in a human breast carcinoma cell line. Biochem. Biophys. Res. Commun. 1987, 144, 1197-1205. [CrossRef] [PubMed]

27. Pietenpol, J.A.; Holt, J.T.; Stein, R.W.; Moses, H.L. Transforming growth factor beta 1 suppression of c-myc gene transcription: Role in inhibition of keratinocyte proliferation. Proc. Natl. Acad. Sci. USA 1990, 87, 3758-3762. [CrossRef] [PubMed]

28. Hannon, G.J.; Beach, D. p15INK4B is a potential effector of TGF-beta-induced cell cycle arrest. Nature 1994, 371, 257-261. [CrossRef] [PubMed]

29. Datto, M.B.; Li, Y.; Panus, J.F.; Howe, D.J.; Xiong, Y.; Wang, X.F. Transforming growth factor beta induces the cyclin-dependent kinase inhibitor p21 through a p53-independent mechanism. Proc. Natl. Acad. Sci. USA 1995, 92, 5545-5549. [CrossRef] [PubMed]

30. Polyak, K.; Kato, J.Y.; Solomon, M.J.; Sherr, C.J.; Massague, J.; Roberts, J.M.; Koff, A. p27Kip1, a cyclin-Cdk inhibitor, links transforming growth factor-beta and contact inhibition to cell cycle arrest. Genes Dev. 1994, 8, 9-22. [CrossRef] [PubMed]

31. Pillaire, M.J.; Casagrande, F.; Malecaze, F.; Manenti, S.; Darbon, J.M. Regulation by transforming growth factor-beta 1 of G1 cyclin-dependent kinases in human retinal epithelial cells. Exp. Eye Res. 1999, 68, 193-199. [CrossRef] [PubMed]

32. Djaborkhel, R.; Tvrdík, D.; Eckschlager, T.; Raska, I.; Müller, J. Cyclin A down-regulation in TGFbeta1-arrested follicular lymphoma cells. Exp. Cell Res. 2000, 261, 250-259. [CrossRef] [PubMed]

33. Cerami, E.; Gao, J.; Dogrusoz, U.; Gross, B.E.; Sumer, S.O.; Aksoy, B.A.; Jacobsen, A.; Byrne, C.J.; Heuer, M.L.; Larsson, E.; et al. The cBio cancer genomics portal: An open platform for exploring multidimensional cancer genomics data. Cancer Discov. 2012, 2, 401-404. [CrossRef] [PubMed]

34. Gao, J.; Aksoy, B.A.; Dogrusoz, U.; Dresdner, G.; Gross, B.; Sumer, S.O.; Sun, Y.; Jacobsen, A.; Sinha, R.; Larsson, E.; et al. Integrative analysis of complex cancer genomics and clinical profiles using the cBioPortal. Sci. Signal. 2013, 6, pl1. [CrossRef] [PubMed]

35. Krasagakis, K.; Thölke, D.; Farthmann, B.; Eberle, J.; Mansmann, U.; Orfanos, C.E. Elevated plasma levels of transforming growth factor (TGF)-beta1 and TGF-beta2 in patients with disseminated malignant melanoma. Br. J. Cancer 1998, 77, 1492-1494. [CrossRef] [PubMed]

36. Kong, F.M.; Anscher, M.S.; Murase, T.; Abbott, B.D.; Iglehart, J.D.; Jirtle, R.L. Elevated plasma transforming growth factor-beta 1 levels in breast cancer patients decrease after surgical removal of the tumor. Ann. Surg. 1995, 222, 155-162. [CrossRef] [PubMed]

37. Ivanović, V.; Demajo, M.; Krtolica, K.; Krajnović, M.; Konstantinović, M.; Baltić, V.; Prtenjak, G.; Stojiljković, B.; Breberina, M.; Nesković-Konstantinović, Z.; et al. Elevated plasma TGF-beta1 levels correlate with decreased survival of metastatic breast cancer patients. Clin. Chim. Acta. 2006, 371, 191-193. [CrossRef] [PubMed] 
38. Friess, H.; Yamanaka, Y.; Büchler, M.; Ebert, M.; Beger, H.G.; Gold, L.I.; Korc, M. Enhanced expression of transforming growth factor beta isoforms in pancreatic cancer correlates with decreased survival. Gastroenterology 1993, 105, 1846-1856. [CrossRef] [PubMed]

39. Mitropoulos, D.; Kiroudi, A.; Christelli, E.; Serafetinidis, E.; Zervas, A.; Anastasiou, I.; Dimopoulos, C. Expression of transforming growth factor beta in renal cell carcinoma and matched non-involved renal tissue. Urol. Res. 2004, 32, 317-322. [CrossRef] [PubMed]

40. Xiong, B.; Gong, L.-L.; Zhang, F.; Hu, M.-B.; Yuan, H.-Y. TGF beta1 expression and angiogenesis in colorectal cancer tissue. World J. Gastroenterol. 2002, 8, 496-498. [CrossRef] [PubMed]

41. Chen, Y.; Ma, L.; He, Q.; Zhang, S.; Zhang, C.; Jia, W. TGF- $\beta 1$ expression is associated with invasion and metastasis of intrahepatic cholangiocarcinoma. Biol. Res. 2015, 48, 26. [CrossRef] [PubMed]

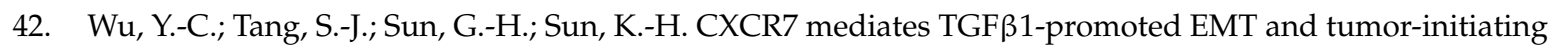
features in lung cancer. Oncogene 2015, 35, 2123-2132. [CrossRef] [PubMed]

43. Kim, J.-W.; Koh, Y.; Kim, D.-W.; Ahn, Y.-O.; Kim, T.M.; Han, S.-W.; Oh, D.-Y.; Lee, S.-H.; Im, S.-A.; Kim, T.-Y.; et al. Clinical Implications of VEGF, TGF- $\beta 1$, and IL-1 $\beta$ in Patients with Advanced Non-small Cell Lung Cancer. Cancer Res. Treat. 2013, 45, 325-333. [CrossRef] [PubMed]

44. Zhuang, J.; Lu, Q.; Shen, B.; Huang, X.; Shen, L.; Zheng, X.; Huang, R.; Yan, J.; Guo, H. TGF $\beta 1$ secreted by cancer-associated fibroblasts induces epithelial-mesenchymal transition of bladder cancer cells through IncRNA-ZEB2NAT. Sci. Rep. 2015, 5, 11924. [CrossRef] [PubMed]

45. Terabe, M.; Matsui, S.; Park, J.-M.; Mamura, M.; Noben-Trauth, N.; Donaldson, D.D.; Chen, W.; Wahl, S.M.; Ledbetter, S.; Pratt, B.; et al. Transforming growth factor-beta production and myeloid cells are an effector mechanism through which CD1d-restricted T cells block cytotoxic T lymphocyte-mediated tumor immunosurveillance: Abrogation prevents tumor recurrence. J. Exp. Med. 2003, 198, 1741-1752. [CrossRef] [PubMed]

46. Ghiringhelli, F.; Puig, P.E.; Roux, S.; Parcellier, A.; Schmitt, E.; Solary, E.; Kroemer, G.; Martin, F.; Chauffert, B.; Zitvogel, L. Tumor cells convert immature myeloid dendritic cells into TGF-beta-secreting cells inducing CD4+CD25+ regulatory T cell proliferation. J. Exp. Med. 2005, 202, 919-929. [CrossRef] [PubMed]

47. Dumitriu, I.E.; Dunbar, D.R.; Howie, S.E.; Sethi, T.; Gregory, C.D. Human dendritic cells produce TGF-beta 1 under the influence of lung carcinoma cells and prime the differentiation of CD4+CD25+Foxp3+ regulatory T cells. J. Immunol. 2009, 182, 2795-2807. [CrossRef] [PubMed]

48. Kadin, M.E.; Cavaille-Coll, M.W.; Gertz, R.; Massagué, J.; Cheifetz, S.; George, D. Loss of receptors for transforming growth factor beta in human T-cell malignancies. Proc. Natl. Acad. Sci. USA 1994, 91, 6002-6006. [CrossRef] [PubMed]

49. Markowitz, S.; Wang, J.; Myeroff, L.; Parsons, R.; Sun, L.; Lutterbaugh, J.; Fan, R.S.; Zborowska, E.; Kinzler, K.W.; Vogelstein, B. Inactivation of the type II TGF-beta receptor in colon cancer cells with microsatellite instability. Science 1995, 268, 1336-1338. [CrossRef] [PubMed]

50. Garrigue-Antar, L.; Muñoz-Antonia, T.; Antonia, S.J.; Gesmonde, J.; Vellucci, V.F.; Reiss, M. Missense mutations of the transforming growth factor beta type II receptor in human head and neck squamous carcinoma cells. Cancer Res. 1995, 55, 3982-3987. [PubMed]

51. Guo, Y.; Jacobs, S.C.; Kyprianou, N. Down-regulation of protein and mRNA expression for transforming growth factor-beta (TGF-beta1) type I and type II receptors in human prostate cancer. Int. J. Cancer 1997, 71, 573-579. [CrossRef] [PubMed]

52. Kim, I.Y.; Ahn, H.J.; Zelner, D.J.; Shaw, J.W.; Lang, S.; Kato, M.; Oefelein, M.G.; Miyazono, K.; Nemeth, J.A.; Kozlowski, J.M.; et al. Loss of expression of transforming growth factor beta type I and type II receptors correlates with tumor grade in human prostate cancer tissues. Clin. Cancer Res. 1996, 2, 1255-1261. [PubMed]

53. Lu, S.-L.; Herrington, H.; Reh, D.; Weber, S.; Bornstein, S.; Wang, D.; Li, A.G.; Tang, C.-F.; Siddiqui, Y.; Nord, J.; et al. Loss of transforming growth factor-beta type II receptor promotes metastatic head-and-neck squamous cell carcinoma. Genes Dev. 2006, 20, 1331-1342. [CrossRef] [PubMed]

54. Schutte, M.; Hruban, R.H.; Hedrick, L.; Cho, K.R.; Nadasdy, G.M.; Weinstein, C.L.; Bova, G.S.; Isaacs, W.B.; Cairns, P.; Nawroz, H.; et al. DPC4 gene in various tumor types. Cancer Res. 1996, 56, 2527-2530. [PubMed]

55. Hahn, S.A.; Hoque, A.T.; Moskaluk, C.A.; da Costa, L.T.; Schutte, M.; Rozenblum, E.; Seymour, A.B.; Weinstein, C.L.; Yeo, C.J.; Hruban, R.H.; et al. Homozygous deletion map at 18q21.1 in pancreatic cancer. Cancer Res. 1996, 56, 490-494. [PubMed] 
56. Eppert, K.; Scherer, S.W.; Ozcelik, H.; Pirone, R.; Hoodless, P.; Kim, H.; Tsui, L.C.; Bapat, B.; Gallinger, S.; Andrulis, I.L.; et al. MADR2 maps to 18q21 and encodes a TGFbeta-regulated MAD-related protein that is functionally mutated in colorectal carcinoma. Cell 1996, 86, 543-552. [CrossRef] [PubMed]

57. Sjöblom, T.; Jones, S.; Wood, L.D.; Parsons, D.W.; Lin, J.; Barber, T.D.; Mandelker, D.; Leary, R.J.; Ptak, J.; Silliman, N.; et al. The consensus coding sequences of human breast and colorectal cancers. Science 2006, 314, 268-274. [CrossRef] [PubMed]

58. Kretzschmar, M.; Doody, J.; Timokhina, I.; Massagué, J. A mechanism of repression of TGFbeta/Smad signaling by oncogenic Ras. Genes Dev. 1999, 13, 804-816. [CrossRef] [PubMed]

59. Kretzschmar, M.; Doody, J.; Massagué, J. Opposing BMP and EGF signalling pathways converge on the TGF-beta family mediator Smad1. Nature 1997, 389, 618-622. [PubMed]

60. Kleeff, J.; Ishiwata, T.; Maruyama, H.; Friess, H.; Truong, P.; Büchler, M.W.; Falb, D.; Korc, M. The TGF-beta signaling inhibitor Smad 7 enhances tumorigenicity in pancreatic cancer. Oncogene 1999, 18, 5363-5372. [CrossRef] [PubMed]

61. Dowdy, S.C.; Mariani, A.; Reinholz, M.M.; Keeney, G.L.; Spelsberg, T.C.; Podratz, K.C.; Janknecht, R. Overexpression of the TGF-beta antagonist Smad 7 in endometrial cancer. Gynecol. Oncol. 2005, 96, 368-373. [CrossRef] [PubMed]

62. Ranganathan, P.; Agrawal, A.; Bhushan, R.; Chavalmane, A.K.; Kalathur, R.; Takahashi, T.; Kondaiah, P. Expression profiling of genes regulated by TGF-beta: Differential regulation in normal and tumour cells. BMC Genom. 2007, 8, 98. [CrossRef] [PubMed]

63. Lebrun, J.-J.; Lebrun, J.-J. The dual role of TGF $\beta$ in human cancer: From tumor suppression to cancer metastasis. ISRN Mol. Biol. 2012, 2012, 1-28. [CrossRef] [PubMed]

64. Albert, M.L.; Jegathesan, M.; Darnell, R.B. Dendritic cell maturation is required for the cross-tolerization of CD8+ T cells. Nat. Immunol. 2001, 2, 1010-1017. [CrossRef] [PubMed]

65. Hawiger, D.; Inaba, K.; Dorsett, Y.; Guo, M.; Mahnke, K.; Rivera, M.; Ravetch, J.V.; Steinman, R.M.; Nussenzweig, M.C. Dendritic cells induce peripheral T cell unresponsiveness under steady state conditions in vivo. J. Exp. Med. 2001, 194, 769-780. [CrossRef] [PubMed]

66. Dhodapkar, M.V.; Steinman, R.M.; Krasovsky, J.; Munz, C.; Bhardwaj, N. Antigen-specific inhibition of effector T cell function in humans after injection of immature dendritic cells. J. Exp. Med. 2001, 193, 233-238. [CrossRef] [PubMed]

67. Matzinger, P. Tolerance, danger, and the extended family. Annu. Rev. Immunol. 1994, 12, 991-1045. [CrossRef] [PubMed]

68. Joffre, O.; Nolte, M.A.; Spörri, R.; Reis e Sousa, C. Inflammatory signals in dendritic cell activation and the induction of adaptive immunity. Immunol. Rev. 2009, 227, 234-247. [CrossRef] [PubMed]

69. Yamaguchi, Y.; Tsumura, H.; Miwa, M.; Inaba, K. Contrasting effects of TGF-beta 1 and TNF-alpha on the development of dendritic cells from progenitors in mouse bone marrow. Stem Cells 1997, 15, 144-153. [CrossRef] [PubMed]

70. Wang, S.; Yang, J.; Qian, J.; Wezeman, M.; Kwak, L.W.; Yi, Q. Tumor evasion of the immune system: Inhibiting p38 MAPK signaling restores the function of dendritic cells in multiple myeloma. Blood 2006, 107, 2432-2439. [CrossRef] [PubMed]

71. Oosterhoff, D.; Lougheed, S.; van de Ven, R.; Lindenberg, J.; van Cruijsen, H.; Hiddingh, L.; Kroon, J.; van den Eertwegh, A.J.M.; Hangalapura, B.; Scheper, R.J.; et al. Tumor-mediated inhibition of human dendritic cell differentiation and function is consistently counteracted by combined p38 MAPK and STAT3 inhibition. Oncoimmunology 2012, 1, 649-658. [CrossRef] [PubMed]

72. Xiang, X.; Poliakov, A.; Liu, C.; Liu, Y.; Deng, Z.; Wang, J.; Cheng, Z.; Shah, S.V.; Wang, G.-J.; Zhang, L.; et al. Induction of myeloid-derived suppressor cells by tumor exosomes. Int. J. Cancer 2009, 124, 2621-2633. [CrossRef] [PubMed]

73. Lechner, M.G.; Megiel, C.; Russell, S.M.; Bingham, B.; Arger, N.; Woo, T.; Epstein, A.L. Functional characterization of human $\mathrm{Cd} 33+$ and $\mathrm{Cd} 11 \mathrm{~b}+$ myeloid-derived suppressor cell subsets induced from peripheral blood mononuclear cells co-cultured with a diverse set of human tumor cell lines. J. Transl. Med. 2011, 9, 90. [CrossRef] [PubMed]

74. Marvel, D.; Gabrilovich, D.I. Myeloid-derived suppressor cells in the tumor microenvironment: Expect the unexpected. J. Clin. Investig. 2015, 125, 3356-3364. [CrossRef] [PubMed] 
75. Ostrand-Rosenberg, S.; Sinha, P. Myeloid-derived suppressor cells: Linking inflammation and cancer. J. Immunol. 2009, 182, 4499-4506. [CrossRef] [PubMed]

76. Geissmann, F.; Revy, P.; Regnault, A.; Lepelletier, Y.; Dy, M.; Brousse, N.; Amigorena, S.; Hermine, O.; Durandy, A. TGF-beta 1 prevents the noncognate maturation of human dendritic Langerhans cells. J. Immunol. 1999, 162, 4567-4575. [PubMed]

77. Laouar, Y.; Town, T.; Jeng, D.; Tran, E.; Wan, Y.; Kuchroo, V.K.; Flavell, R.A. TGF-beta signaling in dendritic cells is a prerequisite for the control of autoimmune encephalomyelitis. Proc. Natl. Acad. Sci. USA 2008, 105, 10865-10870. [CrossRef] [PubMed]

78. Ramalingam, R.; Larmonier, C.B.; Thurston, R.D.; Midura-Kiela, M.T.; Zheng, S.G.; Ghishan, F.K.; Kiela, P.R. Dendritic cell-specific disruption of TGF- $\beta$ receptor II leads to altered regulatory $\mathrm{T}$ cell phenotype and spontaneous multiorgan autoimmunity. J. Immunol. 2012, 189, 3878-3893. [CrossRef] [PubMed]

79. Hargadon, K.M.; Bishop, J.D.; Brandt, J.P.; Hand, Z.C.; Ararso, Y.T.; Forrest, O.A. Melanoma-derived factors alter the maturation and activation of differentiated tissue-resident dendritic cells. Immunol. Cell Biol. 2016, 94, 24-38. [CrossRef] [PubMed]

80. Belladonna, M.L.; Volpi, C.; Bianchi, R.; Vacca, C.; Orabona, C.; Pallotta, M.T.; Boon, L.; Gizzi, S.; Fioretti, M.C.; Grohmann, U.; et al. Cutting edge: Autocrine TGF-beta sustains default tolerogenesis by IDO-competent dendritic cells. J. Immunol. 2008, 181, 5194-5198. [CrossRef] [PubMed]

81. Hargadon, K.M. Tumor-altered dendritic cell function: Implications for anti-tumor immunity. Front. Immunol. 2013, 4, 192. [CrossRef] [PubMed]

82. Scarlett, U.K.; Rutkowski, M.R.; Rauwerdink, A.M.; Fields, J.; Escovar-Fadul, X.; Baird, J.; Cubillos-Ruiz, J.R.; Jacobs, A.C.; Gonzalez, J.L.; Weaver, J.; et al. Ovarian cancer progression is controlled by phenotypic changes in dendritic cells. J. Exp. Med. 2012, 209, 495-506. [CrossRef] [PubMed]

83. Sisirak, V.; Faget, J.; Gobert, M.; Goutagny, N.; Vey, N.; Treilleux, I.; Renaudineau, S.; Poyet, G.; Labidi-Galy, S.I.; Goddard-Leon, S.; et al. Impaired IFN- $\alpha$ production by plasmacytoid dendritic cells favors regulatory T-cell expansion that may contribute to breast cancer progression. Cancer Res. 2012, 72, 5188-5197. [CrossRef] [PubMed]

84. Sisirak, V.; Vey, N.; Goutagny, N.; Renaudineau, S.; Malfroy, M.; Thys, S.; Treilleux, I.; Labidi-Galy, S.I.; Bachelot, T.; Dezutter-Dambuyant, C.; et al. Breast cancer-derived transforming growth factor- $\beta$ and tumor necrosis factor- $\alpha$ compromise interferon- $\alpha$ production by tumor-associated plasmacytoid dendritic cells. Int. J. Cancer 2013, 133, 771-778. [CrossRef] [PubMed]

85. Standiford, T.J.; Kuick, R.; Bhan, U.; Chen, J.; Newstead, M.; Keshamouni, V.G. TGF- $\beta$-induced IRAK-M expression in tumor-associated macrophages regulates lung tumor growth. Oncogene 2011, 30, 2475-2484. [CrossRef] [PubMed]

86. Machado, C.M.L.; Andrade, L.N.S.; Teixeira, V.R.; Costa, F.F.; Melo, C.M.; dos Santos, S.N.; Nonogaki, S.; Liu, F.-T.; Bernardes, E.S.; Camargo, A.A.; et al. Galectin-3 disruption impaired tumoral angiogenesis by reducing VEGF secretion from TGF $\beta 1$-induced macrophages. Cancer Med. 2014, 3, 201-214. [CrossRef] [PubMed]

87. Alleva, D.G.; Walker, T.M.; Elgert, K.D. Induction of macrophage suppressor activity by fibrosarcoma-derived transforming growth factor-beta 1: Contrasting effects on resting and activated macrophages. J. Leukoc. Biol. 1995, 57, 919-928. [PubMed]

88. Cao, Q.; Wang, Y.; Zheng, D.; Sun, Y.; Wang, Y.; Lee, V.W.S.; Zheng, G.; Tan, T.K.; Ince, J.; Alexander, S.I.; et al. IL-10/TGF-beta-modified macrophages induce regulatory $\mathrm{T}$ cells and protect against adriamycin nephrosis. J. Am. Soc. Nephrol. 2010, 21, 933-942. [CrossRef] [PubMed]

89. Galon, J.; Costes, A.; Sanchez-Cabo, F.; Kirilovsky, A.; Mlecnik, B.; Lagorce-Pagès, C.; Tosolini, M.; Camus, M.; Berger, A.; Wind, P.; et al. Type, density, and location of immune cells within human colorectal tumors predict clinical outcome. Science 2006, 313, 1960-1964. [CrossRef] [PubMed]

90. Steidl, C.; Lee, T.; Shah, S.P.; Farinha, P.; Han, G.; Nayar, T.; Delaney, A.; Jones, S.J.; Iqbal, J.; Weisenburger, D.D.; et al. Tumor-associated macrophages and survival in classic Hodgkin's lymphoma. N. Engl. J. Med. 2010, 362, 875-885. [CrossRef] [PubMed]

91. DeNardo, D.G.; Brennan, D.J.; Rexhepaj, E.; Ruffell, B.; Shiao, S.L.; Madden, S.F.; Gallagher, W.M.; Wadhwani, N.; Keil, S.D.; Junaid, S.A.; et al. Leukocyte complexity predicts breast cancer survival and functionally regulates response to chemotherapy. Cancer Discov. 2011, 1, 54-67. [CrossRef] [PubMed] 
92. Kurahara, H.; Shinchi, H.; Mataki, Y.; Maemura, K.; Noma, H.; Kubo, F.; Sakoda, M.; Ueno, S.; Natsugoe, S.; Takao, S. Significance of M2-polarized tumor-associated macrophage in pancreatic cancer. J. Surg. Res. 2011, 167, e211-e219. [CrossRef] [PubMed]

93. Zhang, B.C.; Gao, J.; Wang, J.; Rao, Z.G.; Wang, B.C.; Gao, J.F. Tumor-associated macrophages infiltration is associated with peritumoral lymphangiogenesis and poor prognosis in lung adenocarcinoma. Med. Oncol. 2011, 28, 1447-1452. [CrossRef] [PubMed]

94. Fridlender, Z.G.; Sun, J.; Kim, S.; Kapoor, V.; Cheng, G.; Ling, L.; Worthen, G.S.; Albelda, S.M. Polarization of tumor-associated neutrophil phenotype by TGF-beta: “N1" versus “N2" TAN. Cancer Cell 2009, 16, $183-194$. [CrossRef] [PubMed]

95. Sadot, E.; Basturk, O.; Klimstra, D.S.; Gönen, M.; Lokshin, A.; Do, R.K.G.; D’Angelica, M.I.; DeMatteo, R.P.; Kingham, T.P.; Jarnagin, W.R.; et al. Tumor-associated neutrophils and malignant progression in intraductal papillary mucinous neoplasms. Ann. Surg. 2015, 262, 1102-1107. [CrossRef] [PubMed]

96. Shen, M.; Hu, P.; Donskov, F.; Wang, G.; Liu, Q.; Du, J. Tumor-associated neutrophils as a new prognostic factor in cancer: A systematic review and meta-analysis. PLoS ONE 2014, 9, 646-674. [CrossRef] [PubMed]

97. Fan, Q.-M.; Jing, Y.-Y.; Yu, G.-F.; Kou, X.-R.; Ye, F.; Gao, L.; Li, R.; Zhao, Q.-D.; Yang, Y.; Lu, Z.-H.; et al. Tumor-associated macrophages promote cancer stem cell-like properties via transforming growth factor-beta1-induced epithelial-mesenchymal transition in hepatocellular carcinoma. Cancer Lett. 2014, 352, 160-168. [CrossRef] [PubMed]

98. Tham, M.; Tan, K.W.; Keeble, J.; Wang, X.; Hubert, S.; Barron, L.; Tan, N.S.; Kato, M.; Prevost-Blondel, A.; Angeli, V.; et al. Melanoma-initiating cells exploit M2 macrophage TGF $\beta$ and arginase pathway for survival and proliferation. Oncotarget 2014, 5, 12027-12042. [CrossRef] [PubMed]

99. Shankaran, V.; Ikeda, H.; Bruce, A.T.; White, J.M.; Swanson, P.E.; Old, L.J.; Schreiber, R.D. IFNgamma and lymphocytes prevent primary tumour development and shape tumour immunogenicity. Nature 2001, 410, 1107-1111. [CrossRef] [PubMed]

100. Van den Broek, M.E.; Kägi, D.; Ossendorp, F.; Toes, R.; Vamvakas, S.; Lutz, W.K.; Melief, C.J.; Zinkernagel, R.M.; Hengartner, H. Decreased tumor surveillance in perforin-deficient mice. J. Exp. Med. 1996, 184, 1781-1790. [CrossRef] [PubMed]

101. Smyth, M.J.; Thia, K.Y.; Street, S.E.; MacGregor, D.; Godfrey, D.I.; Trapani, J.A. Perforin-mediated cytotoxicity is critical for surveillance of spontaneous lymphoma. J. Exp. Med. 2000, 192, 755-760. [CrossRef] [PubMed]

102. Penn, I. Tumors of the immunocompromised patient. Annu. Rev. Med. 1988, 39, 63-73. [CrossRef] [PubMed]

103. Dantal, J.; Soulillou, J.-P. Immunosuppressive drugs and the risk of cancer after organ transplantation. N. Engl. J. Med. 2009, 353, 1371-1373. [CrossRef] [PubMed]

104. Halliday, G.M.; Patel, A.; Hunt, M.J.; Tefany, F.J.; Barnetson, R.S.C. Spontaneous regression of human melanoma/nonmelanoma skin cancer: Association with infiltrating CD4+ T cells. World J. Surg. 1995, 19, 352-358. [CrossRef] [PubMed]

105. Yamshchikov, G.; Thompson, L.; Ross, W.G.; Galavotti, H.; Aquila, W.; Deacon, D.; Caldwell, J.; Patterson, J.W.; Hunt, D.F.; Slingluff, C.L. Analysis of a natural immune response against tumor antigens in a melanoma survivor: Lessons applicable to clinical trial evaluations. Clin. Cancer Res. 2001, 7, 909s-916s. [PubMed]

106. Anichini, A.; Scarito, A.; Molla, A.; Parmiani, G.; Mortarini, R. Differentiation of CD8+ T cells from tumor-invaded and tumor-free lymph nodes of melanoma patients: Role of common gamma-chain cytokines. J. Immunol. 2003, 171, 2134-2141. [CrossRef] [PubMed]

107. Zippelius, A.; Batard, P.; Rubio-godoy, V.; Bioley, G.; Lie, D.; Lejeune, F.; Rimoldi, D.; Guillaume, P.; Meidenbauer, N.; Mackensen, A.; et al. Effector function of human tumor-specific CD8 T cells in melanoma lesions: A state of local functional tolerance effector function of human tumor-specific CD8 T cells in melanoma lesions: A state of local functional tolerance. Cancer Res. 2004, 64, 2865-2873. [CrossRef] [PubMed]

108. Mortarini, R.; Piris, A.; Maurichi, A.; Molla, A.; Bersani, I.; Bono, A.; Bartoli, C.; Santinami, M.; Lombardo, C.; Ravagnani, F.; et al. Lack of terminally differentiated tumor-specific CD8+ T cells at tumor site in spite of antitumor immunity to self-antigens in human metastatic melanoma. Cancer Res. 2003, 63, 2535-2545. [PubMed]

109. Fourcade, J.; Sun, Z.; Benallaoua, M.; Guillaume, P.; Luescher, I.F.; Sander, C.; Kirkwood, J.M.; Kuchroo, V.; Zarour, H.M. Upregulation of Tim-3 and PD-1 expression is associated with tumor antigen-specific CD8+ T cell dysfunction in melanoma patients. J. Exp. Med. 2010, 207, 2175-2186. [CrossRef] [PubMed] 
110. Fu, J.; Xu, D.; Liu, Z.; Shi, M.; Zhao, P.; Fu, B.; Zhang, Z.; Yang, H.; Zhang, H.; Zhou, C.; et al. Increased regulatory $\mathrm{T}$ cells correlate with CD8 T-cell impairment and poor survival in hepatocellular carcinoma patients. Gastroenterology 2007, 132, 2328-2339. [CrossRef] [PubMed]

111. Li, M.O.; Sanjabi, S.; Flavell, R.A. Transforming growth factor- $\beta$ controls development, homeostasis, and tolerance of $\mathrm{T}$ cells by regulatory $\mathrm{T}$ cell-dependent and -independent mechanisms. Immunity 2006, 25, 455-471. [CrossRef] [PubMed]

112. Marie, J.C.; Liggitt, D.; Rudensky, A.Y. Cellular mechanisms of fatal early-onset autoimmunity in mice with the T cell-specific targeting of transforming growth factor- $\beta$ receptor. Immunity 2006, 25, 441-454. [CrossRef] [PubMed]

113. Chou, C.K.; Schietinger, A.; Liggitt, H.D.; Tan, X.; Funk, S.; Freeman, G.J.; Ratliff, T.L.; Greenberg, N.M.; Greenberg, P.D. Cell-intrinsic abrogation of TGF- $\beta$ signaling delays but does not prevent dysfunction of self/tumor-specific CD8 T cells in a murine model of autochthonous prostate cancer. J. Immunol. 2012, 189, 3936-3946. [CrossRef] [PubMed]

114. Xie, Y.; Bai, O.; Yuan, J.; Chibbar, R.; Slattery, K.; Wei, Y.; Deng, Y.; Xiang, J. Tumor apoptotic bodies inhibit CTL responses and antitumor immunity via membrane-bound transforming growth factor-beta1 inducing CD8+ T-cell anergy and CD4+ Tr1 cell responses. Cancer Res. 2009, 69, 7756-7766. [CrossRef] [PubMed]

115. Shvedova, A.A.; Kisin, E.R.; Yanamala, N.; Tkach, A.V.; Gutkin, D.W.; Star, A.; Shurin, G.V.; Kagan, V.E.; Shurin, M.R. MDSC and TGF $\beta$ are required for facilitation of tumor growth in the lungs of mice exposed to carbon nanotubes. Cancer Res. 2015, 75, 1615-1623. [CrossRef] [PubMed]

116. Chen, W.; Jin, W.; Hardegen, N.; Lei, K.-J.; Li, L.; Marinos, N.; McGrady, G.; Wahl, S.M. Conversion of peripheral CD4+CD25- naive $\mathrm{T}$ cells to $\mathrm{CD} 4+\mathrm{CD} 25+$ regulatory $\mathrm{T}$ cells by TGF-beta induction of transcription factor Foxp3. J. Exp. Med. 2003, 198, 1875-1886. [CrossRef] [PubMed]

117. Patel, S.A.; Meyer, J.R.; Greco, S.J.; Corcoran, K.E.; Bryan, M.; Rameshwar, P. Mesenchymal stem cells protect breast cancer cells through regulatory T cells: Role of mesenchymal stem cell-derived TGF-beta. J. Immunol. 2010, 184, 5885-5894. [CrossRef] [PubMed]

118. Huang, B.; Pan, P.-Y.; Li, Q.; Sato, A.I.; Levy, D.E.; Bromberg, J.; Divino, C.M.; Chen, S.-H. Gr-1+CD115+ immature myeloid suppressor cells mediate the development of tumor-induced T regulatory cells and T-cell anergy in tumor-bearing host. Cancer Res. 2006, 66, 1123-1131. [CrossRef] [PubMed]

119. Shurin, G.V.; Ma, Y.; Shurin, M.R. Immunosuppressive mechanisms of regulatory dendritic cells in cancer. Cancer Microenviron. 2013, 6, 159-167. [CrossRef] [PubMed]

120. Nakamura, K.; Kitani, A.; Strober, W. Cell contact-dependent immunosuppression by CD4(+)CD25(+) regulatory $\mathrm{T}$ cells is mediated by cell surface-bound transforming growth factor beta. J. Exp. Med. 2001, 194, 629-644. [CrossRef] [PubMed]

121. Chen, M.-L.; Pittet, M.J.; Gorelik, L.; Flavell, R.A.; Weissleder, R.; von Boehmer, H.; Khazaie, K. Regulatory T cells suppress tumor-specific CD8 T cell cytotoxicity through TGF-beta signals in vivo. Proc. Natl. Acad. Sci. USA 2005, 102, 419-424. [CrossRef] [PubMed]

122. De Jong, E.; Suddason, T.; Lord, G.M. Translational mini-review series on Th17 cells: Development of mouse and human T helper 17 cells. Clin. Exp. Immunol. 2010, 159, 148-158. [CrossRef] [PubMed]

123. Zou, W.; Restifo, N.P. T(H)17 cells in tumour immunity and immunotherapy. Nat. Rev. Immunol. 2010, 10, 248-256. [CrossRef] [PubMed]

124. Wang, L.; Yi, T.; Kortylewski, M.; Pardoll, D.M.; Zeng, D.; Yu, H. IL-17 can promote tumor growth through an IL-6-Stat3 signaling pathway. J. Exp. Med. 2009, 206, 1457-1464. [CrossRef] [PubMed]

125. He, D.; Li, H.; Yusuf, N.; Elmets, C.A.; Li, J.; Mountz, J.D.; Xu, H. IL-17 promotes tumor development through the induction of tumor promoting microenvironments at tumor sites and myeloid-derived suppressor cells. J. Immunol. 2010, 184, 2281-2288. [CrossRef] [PubMed]

126. De Simone, V.; Franzè, E.; Ronchetti, G.; Colantoni, A.; Fantini, M.C.; di Fusco, D.; Sica, G.S.; Sileri, P.; MacDonald, T.T.; Pallone, F.; et al. Th17-type cytokines, IL- 6 and TNF- $\alpha$ synergistically activate STAT3 and NF-kB to promote colorectal cancer cell growth. Oncogene 2015, 34, 3493-3503. [CrossRef] [PubMed]

127. Prabhala, R.H.; Pelluru, D.; Fulciniti, M.; Prabhala, H.K.; Nanjappa, P.; Song, W.; Pai, C.; Amin, S.; Tai, Y.-T.; Richardson, P.G.; et al. Elevated IL-17 produced by TH17 cells promotes myeloma cell growth and inhibits immune function in multiple myeloma. Blood 2010, 115, 5385-5392. [CrossRef] [PubMed] 
128. Iida, T.; Iwahashi, M.; Katsuda, M.; Ishida, K.; Nakamori, M.; Nakamura, M.; Naka, T.; Ojima, T.; Ueda, K.; Hayata, K.; et al. Tumor-infiltrating CD4+ Th17 cells produce IL-17 in tumor microenvironment and promote tumor progression in human gastric cancer. Oncol. Rep. 2011, 25, 1271-1277. [PubMed]

129. Zhang, J.-P.; Yan, J.; Xu, J.; Pang, X.-H.; Chen, M.-S.; Li, L.; Wu, C.; Li, S.-P.; Zheng, L. Increased intratumoral IL-17-producing cells correlate with poor survival in hepatocellular carcinoma patients. J. Hepatol. 2009, 50, 980-989. [CrossRef] [PubMed]

130. Waldhauer, I.; Steinle, A. NK cells and cancer immunosurveillance. Oncogene 2008, 27, 5932-5943. [CrossRef] [PubMed]

131. Li, H.; Han, Y.; Guo, Q.; Zhang, M.; Cao, X. Cancer-expanded myeloid-derived suppressor cells induce anergy of NK cells through membrane-bound TGF-beta 1. J. Immunol. 2009, 182, 240-249. [CrossRef] [PubMed]

132. Sui, Q.; Zhang, J.; Sun, X.; Zhang, C.; Han, Q.; Tian, Z. NK cells are the crucial antitumor mediators when STAT3-mediated immunosuppression is blocked in hepatocellular carcinoma. J. Immunol. 2014, 193, 2016-2023. [CrossRef] [PubMed]

133. Dasgupta, S.; Bhattacharya-Chatterjee, M.; O'Malley, B.W.; Chatterjee, S.K. Inhibition of NK cell activity through TGF-1 by down-regulation of NKG2D in a murine model of head and neck cancer. J. Immunol. 2005, 175, 5541-5550. [CrossRef] [PubMed]

134. Donatelli, S.S.; Zhou, J.-M.; Gilvary, D.L.; Eksioglu, E.A.; Chen, X.; Cress, W.D.; Haura, E.B.; Schabath, M.B.; Coppola, D.; Wei, S.; et al. TGF-inducible microRNA-183 silences tumor-associated natural killer cells. Proc. Natl. Acad. Sci. USA 2014, 111, 4203-4208. [CrossRef] [PubMed]

135. Viel, S.; Marçais, A.; Guimaraes, F.S.-F.; Loftus, R.; Rabilloud, J.; Grau, M.; Degouve, S.; Djebali, S.; Sanlaville, A.; Charrier, E.; et al. TGF- $\beta$ inhibits the activation and functions of NK cells by repressing the mTOR pathway. Sci. Signal. 2016, 9. [CrossRef] [PubMed]

136. Lee, J.-C.; Lee, K.-M.; Kim, D.-W.; Heo, D.S. Elevated TGF-1 secretion and down-modulation of NKG2D underlies impaired NK cytotoxicity in cancer patients. J. Immunol. 2004, 172, 7335-7340. [CrossRef] [PubMed]

137. Yoon, S.J.; Heo, D.S.; Kang, S.H.; Lee, K.H.; Kim, W.S.; Kim, G.P.; Lee, J.A.; Lee, K.S.; Bang, Y.J.; Kim, N.K. Natural killer cell activity depression in peripheral blood and ascites from gastric cancer patients with high TGF-beta 1 expression. Anticancer Res. 1997, 18, 1591-1596.

138. Kim, S.; Buchlis, G.; Fridlender, Z.G.; Sun, J.; Kapoor, V.; Cheng, G.; Haas, A.; Cheung, H.K.; Zhang, X.; Corbley, M.; et al. Systemic blockade of transforming growth factor-beta signaling augments the efficacy of immunogene therapy. Cancer Res. 2008, 68, 10247-10256. [CrossRef] [PubMed]

139. Suzuki, E.; Kapoor, V.; Cheung, H.K.; Ling, L.E.; DeLong, P.A.; Kaiser, L.R.; Albelda, S.M. Soluble type II transforming growth factor-beta receptor inhibits established murine malignant mesothelioma tumor growth by augmenting host antitumor immunity. Clin. Cancer Res. 2004, 10, 5907-5918. [CrossRef] [PubMed]

140. Takaku, S.; Terabe, M.; Ambrosino, E.; Peng, J.; Lonning, S.; McPherson, J.M.; Berzofsky, J.A. Blockade of TGF-beta enhances tumor vaccine efficacy mediated by CD8(+) T cells. Int. J. Cancer 2010, 126, 1666-1674. [PubMed]

141. Penafuerte, C.; Bautista-Lopez, N.; Bouchentouf, M.; Birman, E.; Forner, K.; Galipeau, J. Novel TGF-beta antagonist inhibits tumor growth and angiogenesis by inducing IL-2 receptor-driven STAT1 activation. J. Immunol. 2011, 186, 6933-6944. [CrossRef] [PubMed]

142. Conroy, H.; Galvin, K.C.; Higgins, S.C.; Mills, K.H.G. Gene silencing of TGF- $\beta 1$ enhances antitumor immunity induced with a dendritic cell vaccine by reducing tumor-associated regulatory $\mathrm{T}$ cells. Cancer Immunol. Immunother. 2012, 61, 425-431. [CrossRef] [PubMed]

143. Sakuraba, H.; Ishiguro, Y.; Yamagata, K.; Munakata, A.; Nakane, A. Blockade of TGF- $\beta$ accelerates mucosal destruction through epithelial cell apoptosis. Biochem. Biophys. Res. Commun. 2007, 359, 406-412. [CrossRef] [PubMed]

144. Rodrigues-Díez, R.; Rayego-Mateos, S.; Orejudo, M.; Aroeira, L.S.; Selgas, R.; Ortiz, A.; Egido, J.; Ruiz-Ortega, M. TGF-beta blockade increases renal inflammation caused by the C-terminal module of the CCN2. Mediat. Inflamm. 2015, 2015, 506041. [CrossRef] [PubMed] 
145. Lacouture, M.E.; Morris, J.C.; Lawrence, D.P.; Tan, A.R.; Olencki, T.E.; Shapiro, G.I.; Dezube, B.J.; Berzofsky, J.A.; Hsu, F.J.; Guitart, J. Cutaneous keratoacanthomas/squamous cell carcinomas associated with neutralization of transforming growth factor $\beta$ by the monoclonal antibody fresolimumab (GC1008). Cancer Immunol. Immunother. 2015, 64, 437-446. [CrossRef] [PubMed]

146. Zhang, Q.; Yang, X.J.; Kundu, S.D.; Pins, M.; Javonovic, B.; Meyer, R.; Kim, S.-J.; Greenberg, N.M.; Kuzel, T.; Meagher, R.; et al. Blockade of transforming growth factor-\{beta\} signaling in tumor-reactive CD8(+) T cells activates the antitumor immune response cycle. Mol. Cancer Ther. 2006, 5, 1733-1743. [CrossRef] [PubMed]

147. Zhang, Q.; Yang, X.; Pins, M.; Javonovic, B.; Kuzel, T.; Kim, S.-J.; van Parijs, L.; Greenberg, N.M.; Liu, V.; Guo, Y.; et al. Adoptive transfer of tumor-reactive transforming growth factor-beta-insensitive CD8+ T cells: Eradication of autologous mouse prostate cancer. Cancer Res. 2005, 65, 1761-1769. [CrossRef] [PubMed]

148. Zhang, Q.; Jang, T.L.; Yang, X.; Park, I.; Meyer, R.E.; Kundu, S.; Pins, M.; Javonovic, B.; Kuzel, T.; Kim, S.-J.; et al. Infiltration of tumor-reactive transforming growth factor-beta insensitive CD8+ T cells into the tumor parenchyma is associated with apoptosis and rejection of tumor cells. Prostate 2006, 66, 235-247. [CrossRef] [PubMed]

149. Gate, D.; Danielpour, M.; Rodriguez, J.; Kim, G.-B.; Levy, R.; Bannykh, S.; Breunig, J.J.; Kaech, S.M.; Flavell, R.A.; Town, T. T-cell TGF- $\beta$ signaling abrogation restricts medulloblastoma progression. Proc. Natl. Acad. Sci. USA 2014, 111, E3458-E3466. [CrossRef] [PubMed]

150. Zhang, L.; Yu, Z.; Muranski, P.; Palmer, D.C.; Restifo, N.P.; Rosenberg, S.A.; Morgan, R.A. Inhibition of TGF- $\beta$ signaling in genetically engineered tumor antigen-reactive $\mathrm{T}$ cells significantly enhances tumor treatment efficacy. Gene Ther. 2013, 20, 575-580. [CrossRef] [PubMed]

151. Foster, A.E.; Dotti, G.; Lu, A.; Khalil, M.; Brenner, M.K.; Heslop, H.E.; Rooney, C.M.; Bollard, C.M. Antitumor activity of EBV-specific T lymphocytes transduced with a dominant negative TGF-beta receptor. J. Immunother. 2008, 31, 500-505. [CrossRef] [PubMed]

152. Lacuesta, K.; Buza, E.; Hauser, H.; Granville, L.; Pule, M.; Corboy, G.; Finegold, M.; Weiss, H.; Chen, S.Y.; Brenner, M.K.; et al. Assessing the safety of cytotoxic T lymphocytes transduced with a dominant negative transforming growth factor-beta receptor. J. Immunother. 2006, 29, 250-260. [CrossRef] [PubMed]

153. Wang, F.-L.; Qin, W.-J.; Wen, W.-H.; Tian, F.; Song, B.; Zhang, Q.; Lee, C.; Zhong, W.; Guo, Y.-L.; Wang, H. TGF-beta insensitive dendritic cells: An efficient vaccine for murine prostate cancer. Cancer Immunol. Immunother. 2007, 56, 1785-1793. [CrossRef] [PubMed]

154. Tian, F.; Wang, L.; Qin, W.; Wang, F.; Song, B.; Li, Y.; Wen, W.; Zhang, Z.; Zhu, K.; Zhang, Q.; et al. Vaccination with transforming growth factor-beta insensitive dendritic cells suppresses pulmonary metastases of renal carcinoma in mice. Cancer Lett. 2008, 271, 333-341. [CrossRef] [PubMed]

155. Ahn, Y.-H.; Hong, S.-O.; Kim, J.H.; Noh, K.H.; Song, K.-H.; Lee, Y.-H.; Jeon, J.-H.; Kim, D.-W.; Seo, J.H.; Kim, T.W. The siRNA cocktail targeting interleukin 10 receptor and transforming growth factor- $\beta$ receptor on dendritic cells potentiates tumour antigen-specific CD8(+) T cell immunity. Clin. Exp. Immunol. 2015, 181, 164-178. [CrossRef] [PubMed]

156. Cubillos-Ruiz, J.R.; Baird, J.R.; Tesone, A.J.; Rutkowski, M.R.; Scarlett, U.K.; Camposeco-Jacobs, A.L.; Anadon-Arnillas, J.; Harwood, N.M.; Korc, M.; Fiering, S.N.; et al. Reprogramming tumor-associated dendritic cells in vivo using miRNA mimetics triggers protective immunity against ovarian cancer. Cancer Res. 2012, 72, 1683-1693. [CrossRef] [PubMed]

157. Neuzillet, C.; Tijeras-Raballand, A.; Cohen, R.; Cros, J.; Faivre, S.; Raymond, E.; de Gramont, A. Targeting the TGF $\beta$ pathway for cancer therapy. Pharmacol. Ther. 2015, 147, 22-31. [CrossRef] [PubMed]

158. Stevenson, J.P.; Kindler, H.L.; Papasavvas, E.; Sun, J.; Jacobs-Small, M.; Hull, J.; Schwed, D.; Ranganathan, A.; Newick, K.; Heitjan, D.F.; et al. Immunological effects of the TGF $\beta$-blocking antibody GC1008 in malignant pleural mesothelioma patients. Oncoimmunology 2013, 2, e26218. [CrossRef] [PubMed]

159. Senzer, N.; Barve, M.; Kuhn, J.; Melnyk, A.; Beitsch, P.; Lazar, M.; Lifshitz, S.; Magee, M.; Oh, J.; Mill, S.W.; et al. Phase I trial of \& quot;bi-shRNAi(furin)/GMCSF DNA/autologous tumor cell \& quot; vaccine (FANG) in advanced cancer. Mol. Ther. 2012, 20, 679-686. [PubMed]

160. Senzer, N.; Barve, M.; Nemunaitis, J.; Kuhn, J.; Melnyk, A.; Beltsch, P.; Magee, M.; Oh, J.; Bedell, C.; Kumar, P.; et al. Long term follow up: Phase I trial of "bi-shRNA furin/GMCSF DNA/Autologous tumor cell" immunotherapy (FANG ${ }^{\mathrm{TM}}$ ) in advanced cancer. J. Vaccines Vaccin. 2013, 4, 8. 
161. Nemunaitis, J.; Barve, M.; Orr, D.; Kuhn, J.; Magee, M.; Lamont, J.; Bedell, C.; Wallraven, G.; Pappen, B.O.; Roth, A.; et al. Summary of bi-shRNA/GM-CSF augmented autologous tumor cell immunotherapy (FANG ${ }^{\mathrm{TM}}$ ) in advanced cancer of the liver. Oncology 2014, 87, 21-29. [CrossRef] [PubMed]

162. Ghisoli, M.; Barve, M.; Schneider, R.; Mennel, R.; Lenarsky, C.; Wallraven, G.; Pappen, B.O.; LaNoue, J.; Kumar, P.; Nemunaitis, D.; et al. Pilot trial of FANG immunotherapy in ewing's sarcoma. Mol. Ther. 2015, 23, 1103-1109. [CrossRef] [PubMed]

163. Ghisoli, M.; Barve, M.; Mennel, R.; Lenarsky, C.; Horvath, S.; Wallraven, G.; Pappen, B.O.; Whiting, S.; Rao, D.; Senzer, N.; et al. Three year follow up of GMCSF/bi-shRNA(furin) DNA transfected autologous tumor immunotherapy (Vigil( $\left.{ }^{\mathrm{TM}}\right)$ ) in metastatic advanced ewing's sarcoma. Mol. Ther. 2016. [CrossRef] [PubMed]

(C) 2016 by the author; licensee MDPI, Basel, Switzerland. This article is an open access article distributed under the terms and conditions of the Creative Commons Attribution (CC-BY) license (http://creativecommons.org/licenses/by/4.0/). 